\title{
Karışımlar Konusunun Öğretilmesinde İşbirlikli Öğrenme Yönteminin İyi Bir Eğitim Ortamı İçin Yedi İlke ve Modellerle Kullanılması
}

\author{
Oylum Çavdar ${ }^{1}$, Kemal Doymuş ${ }^{2}$ \\ ${ }^{1}$ Matematik ve Fen Bilimleri Ĕgitimi Bölümü, Eğitim Fakültesi, Muş Alparslan Üniversitesi, Muş, Türkiye \\ ${ }^{2}$ Matematik ve Fen Bilimleri Eğitimi Bölümü, Eğitim Fakültesi, Atatürk Üniversitesi, Erzurum, Türkiye
}

Sorumlu Yazar: Oylum Çavdar, o.cavdar@alparslan.edu.tr

Makale Türü: Araştırma Makalesi

Bilgilendirme: Bu makale, birinci yazarın ikinci yazarın danışmanlığında Atatürk Üniversitesi Eğitim Bilimleri Enstitüsü’nde tamamladığı doktora tezine dayalı olarak hazırlanmıştır.

Kaynak Gösterimi: Çavdar, O., \& Doymuş, K. (2018). Karışımlar konusunun öğretilmesinde işbirlikli öğrenme yönteminin iyi bir eğitim ortamı için yedi ilke ve modellerle kullanılması. Eğitimde Kuram ve Uygulama, 14(3), 325-346. doi:10.17244/eku.328018

\section{The Using of Cooperative Learning Method with Seven Principles for Good Practice and Models in Teaching of the Subject of Mixtures}

\author{
Oylum Çavdar ${ }^{1}$, Kemal Doymuş ${ }^{2}$ \\ ${ }^{1}$ Department of Mathematics and Science Education, Faculty of Education, Muş Alparslan University, Muş, Turkey \\ ${ }^{2}$ Department of Mathematics and Science Education, Faculty of Education, Atatürk University, Erzurum, Turkey
}

Corresponding Author: Oylum Çavdar, o.cavdar@alparslan.edu.tr

Article Type: Research Article

Acknowledgement: This article was generated based on the first author's doctoral thesis completed under the guidance of the second author at the Graduate School of Educational Sciences, Atatürk University, Erzurum, Turkey.

To Cite This Article: Çavdar, O., \& Doymuş, K. (2018). Karışımlar konusunun öğretilmesinde işbirlikli öğrenme yönteminin iyi bir eğitim ortamı için yedi ilke ve modellerle kullanılması. Eğitimde Kuram ve Uygulama, 14(3), 325-346. doi:10.17244/eku.328018 


\title{
Karışımlar Konusunun Öğretilmesinde İşbirlikli Öğrenme Yönteminin İyi Bir Eğitim Ortamı İçin Yedi İlke ve Modellerle Kullanılması
}

\author{
Oylum Çavdar' ${ }^{1}$ Kemal Doymuş² \\ ${ }^{1}$ Matematik ve Fen Bilimleri Eğitimi Bölümü, Eğitim Fakültesi, Muş Alparslan Üniversitesi, Muş, Türkiye \\ ORCID: http://orcid.org/0000-0001-8405-0969 \\ ${ }^{2}$ Matematik ve Fen Bilimleri Ĕ̆itimi Bölümü, Eğitim Fakültesi, Atatürk Üniversitesi, Erzurum, Türkiye \\ ORCID: http://orcid.org/0000-0002-0578-5623
}

\begin{abstract}
Öz
Bu araştırmanın amacı 7. sınıf "Karışımlar" konusunun işbirlikli öğrenme yöntemi, yedi ilke ve modellerle öğretilmesinin öğrencilerin mikro boyuttaki kavramsal anlamalarına etkisini araştırmaktır. Araştırmada nicel araştırma yöntemlerinden yarı deneysel desen kullanılmış ve üç araştırma grubu belirlenmiştir. İşbirlikli Yedi İlke Model Grubunda (IYYMG) işbirlikli öğrenme yöntemi ile iyi bir eğitim ortamı için yedi ilke ve modellerle birlikte kullanılarak, İşbirlikli Yedi İlke Grubunda (IYYG) işbirlikli öğrenme yöntemi ile iyi bir eğitim ortamı için yedi ilke kullanılarak, İşbirlikli Grupta (İG) ise işbirlikli öğrenme yöntemi ile öğretilmiştir. Çalışmalar bittikten sonra öğrencilerin mikro boyuttaki çizimlerini gerektiren üç sorudan oluşan açık uçlu Model Çizim Testi (MÇT) gruplara uygulanmıştır. Verilerin çözümlenmesinde betimleyici istatistiklerden ortalama ve standart sapma, anlamlılık analizleri için ise tek yönlü varyans analizi (One Way ANOVA) kullanılmıştır. Daha sonra gruplardaki öğrencilerin sahip oldukları yanlış anlamalar MÇT'nin her sorusu için ayrı ayrı tespit edilmiş, tablolar halinde sunulmuştur. Son olarak, gruplarda bu yanlış anlamalara sahip öğrenci çizimlerinden örnekler çizimi yapan öğrencinin koduyla (Ö1, Ö2, Ö3...) birlikte olduğu gibi sergilenmiştir. Araştırmanın sonunda modellerin ve yedi ilkenin karışımlar konusunda öğrencilerin mikro boyuttaki anlamalarını istatistiksel olarak anlamlı derecede artırdığı tespit edilmiştir. Ayrıca çalışmada araştırma gruplarındaki öğrencilerin zihinlerinde tuzun, şekerin ve alkolün suda çözünmesiyle ilgili hatalı modellerin olduğu ortaya çıkmıştır.
\end{abstract}

\section{Makale Bilgisi}

Anahtar Kelimeler: Yedi ilke, Modeler, İşbirlikli öğrenme, Karıșımlar

Makale Geçmiși:

Geliş: 12 Temmuz 2017

Düzeltme: 28 Ekim 2017

Kabul: 12 Aralık 2017

Makale Türü: Araştırma Makalesi 


\section{The Using of Cooperative Learning Method with Seven Principles for Good Practice and Models in Teaching of the Subject of Mixtures}

\begin{tabular}{|c|c|}
\hline Abstract & Article Info \\
\hline $\begin{array}{l}\text { The aim of this study was examining the effect of teaching the subject of Mixtures at 7th } \\
\text { grade with cooperative learning methodology, seven principles and models to students' } \\
\text { conceptual understanding at micro level. Quasi-experimental design was used in } \\
\text { quantitative research methods and determined three experiment groups. In Cooperative }\end{array}$ & $\begin{array}{l}\text { Keywords: Seven principles, } \\
\text { Models, Cooperative learning, } \\
\text { Mixtures }\end{array}$ \\
\hline $\begin{array}{l}\text { Seven Principles Model Group (CSPMG), seven principles for good practice and models } \\
\text { were used with cooperative learning method, in Cooperative Seven Principles Group } \\
\text { (CSPG), seven principles for good practice were used with cooperative learning method } \\
\text { and in Cooperative Group (CG), cooperative learning method in teaching the subjects. }\end{array}$ & $\begin{array}{l}\text { Article History: } \\
\text { Received: } 12 \text { July } 2017 \\
\text { Revised: } 28 \text { October } 2017\end{array}$ \\
\hline $\begin{array}{l}\text { After the studies, the open-ended Model Drawing Test (MÇT) consisting of three } \\
\text { questions that required students' drawing at micro level was applied to the groups. For the }\end{array}$ & Accepted: 12 December 2017 \\
\hline $\begin{array}{l}\text { analysis of data, mean, standard deviation of descriptive statistics, One Way ANOVA of } \\
\text { significance analyzes were used. Later, the students' misunderstandings in the groups } \\
\text { were determined separately for each question of the MÇT and presented in tabular form. }\end{array}$ & Article Type: Research Article \\
\hline $\begin{array}{l}\text { Finally, in the groups, the student drawings with these misconceptions were exhibited as if } \\
\text { they were accompanied by the code (Ö1, Ö2, Ö3 ...). The end of the study, it was } \\
\text { determined that the seven principles and models applications were improved statistically } \\
\text { students' conceptual understanding significantly in the subject at micro level. In addition, } \\
\text { it has been found out that the students in the research groups have inaccurate models } \\
\text { regarding the dissolution of salt, sugar and alcohol in the water of their minds. }\end{array}$ & \\
\hline
\end{tabular}




\section{Giriş}

Fen bilimleri dersindeki kimya konuları birçok soyut kavram içermektedir ve bu durum da öğrencilerin yeterli düzeyde uygun anlamalar geliştirmelerini zorlaştırmaktadır (Demircioğlu, Demircioğlu, Ayas, \& Kongur, 2012; Papageorgiou, Stamovlasis, \& Johnson, 2010). Oysaki atom, molekül, element, bileşik gibi kavramlar öğrenciler için ileriki sınıflara ve üniversiteye temel oluşturacak niteliktedir. Bu nedenle ortaokulda bu konularında oluşacak yanlış anlamalar daha sonraki sınıflarda yeni karşılaşılan konu ve kavramların öğrenilmesini zorlaştırabilir (Koştur, 2009). Buna karşın zihinsel gelişmişlik düzeyi henüz çok soyut kavramları anlayabilecek düzeye yeterince ulaşmamış ortaokul öğrencilerine, zaten çok soyut olan ve zor öğrenilebilen bir kavram olan maddenin mikroskobik yapısının öğretilmesi ilave bir zorluk yaşatmaktadır (Say, 2011). Kimya kavramlarının anlaşılmasında makro, mikro ve sembolik boyut olmak üzere üç kavramsal boyuttan söz edilmektedir. Makro boyut, gözlemlenebilir olaylar, deneyler ve deneyimlerle; mikro boyut, yapısal formüller ve zihinsel görüntülerle; sembolik boyut ise grafikler, kimyasal denklemler gibi resimsel ve cebirsel formüllerle ilgilidir (Ebenezer, 2001; Meijer, 2011; Özmen \& Ayas, 2003). Bu boyutlar arasındaki bağlantıların uygun şekilde kurulamaması durumunda öğrencilerde soyut konuları anlamada eksiklikler, kavram yanılgıları veya zihinlerinde yanlış canlandırmalar oluşabilmektedir. Nitekim literatürde farklı yaş gruplarındaki öğrencilerin büyük bir kısmının maddenin tanecikli yapısını doğru bir şekilde kavrayamadıkları tespit edilmiştir (Aydeniz \& Kotowsk, 2012; Ergün, 2013; Karagöz \& Sağlam-Arslan, 2012; Meşeci, Tekin, \& Karamustafaoğlu, 2013; Saydam, 2013). Konularının somutlaştırılması ve daha eğlenceli hale getirilmesi bu kavrama problemlerinin önüne geçilmesi açısından büyük önem arz etmektedir. Konu ile ilişkilendirilen modellerin kullanılması soyut kavramları zihinde somutlaştırarak anlamlı ve kolay öğrenmeyi sağlayan etkili ve eğlenceli bir yoldur (Sarıkaya, Selvi, \& Doğan-Bora, 2004). Teorik bilgilerin modellerle somutlaştırılması en karmaşık olayların bile kolay öğretilmesini/öğrenilmesini sağlamaktadır (Sadıç \& Çam 2012). Mikro boyuttaki olayların öğrenciler tarafindan tam ve doğru olarak anlaşılması için atomların, moleküllerin, teorik kavramların modellerle öğretilmesi önemlidir (Adadan, 2014; Ergün, 2013; Philipp, Johnson, \& Yezierski, 2014). Öğrenciler yalnızca işittikleri şeyleri kolayca unutmaktadır. Oysa bizzat katıldıkları bir öğretim etkinliği, onların konuyu daha iyi anlamalarını sağlamaktadır. Konunun gözle görülmesi, elle tutulması, parçalara ayrılabilmesi öğrenilmesini kolaylaştırır. Ayrıca modelleri bizzat öğrencinin kendisine yaptırmak o kavramı öğrencinin daha iyi öğrenmesine yardımcı olmaktadır (Küçükahmet, 2000). Öğrenciler konuların somutlaştırılması için el ile yapılan bu etkinliklere aktif olarak katılmalıdırlar (Friedler \& Tamır, 1990). Bu bağlamda maddenin tanecikli yapısı konusunun derinlemesine ve kalıcı öğrenebilmesi için aktif öğrenme yaklaşımları kullanılmalıdır (Balım \& Ormanc1, 2012). Kimyanın üç seviyede de (makroskobik, mikroskobik ve sembolik) anlaşılması için aktif öğrenme yöntemlerinden işbirlikli öğrenme, projeye dayalı öğrenme, probleme dayalı öğrenme ve sorgulamaya dayalı öğrenme yöntemleri önerilmektedir (Cuevas, Lee, Hart, \& Deaktor, 2005). Bu yöntemlerden işbirlikli öğrenmenin modellerle birlikte uygulanması öğrencilerin kavramsal anlamalarını kolaylaştırmaktadır (Çavdar \& Doymuş, 2016; Çavdar, Okumuş, Alyar, \& Doymuş, 2016). İşbirlikli öğrenme öğrencilerin kimya konusunda anlama güçlüklerini gidermede etkili bir yöntemdir (Acar \& Tarhan, 2008; Doymuş, Karaçöp, \& Şimşek, 2010; Doymuş, Şimşek, \& Karaçöp, 2009; Karaçöp \& Doymuş, 2012). Diğer taraftan işbirlikli öğrenmenin kavrama düzeylerini artırdığı da yapılan çalışmalarla ortaya konmuştur (Barbosa, Jofili, \& Watts, 2004; Nakiboğlu, 2001; Shachar \& Fisher, 2004).

Chickering ve Gamson (1987) iyi bir eğitim ortamını yedi ilke altında özetlemiştir. Bunlar; öğrenci-fakülte etkileşiminin sağlanması, öğrenciler arası işbirliğinin sağlanması, aktif öğrenmenin kullanılması, anlı geribildirimlerin verilmesi, görevlerin zamanında yapılmasının sağlanması, üst düzey ulaş1labilir beklentilere cevap verilmesi, farklı yetenek ve öğrenme stillerine karşı toleranslı olunmasıdır (Chickering \& Gamson, 1987). İyi bir öğrenme ortamı sağlayan bu ilkeler eğitimde belirli standartlar oluşturmak ve yüz yüze öğretimde kaliteyi artırmak (Chickering \& Gamson, 1987; Collard, 2009), azalan öğrenci performans1, ilgisi ve yetersiz öğretme stratejileri gibi sorunların çözümü için geliştirilmiştir (Aydoğdu, 2012). Chickering ve Gamson (1987) aktif öğrenme yöntemlerinin etkililiğini arttırmak için aktif öğrenme yöntemleri ile iyi bir eğitim ortamını sağlayan yedi ilkenin eğitim sürecinde uygulanması gerektiğini belirtmektedir. Nitekim aktif öğrenme ve işbirliğinin sağlanması yedi ilkenin ilkeleri arasındadır. İlkeler geleneksel sınıf ortamlarında uygulamaları geliştirmek amacıyla kullanılmasına rağmen, literatürde ortaokul düzeyinde ve öğrenci merkezli öğretim yöntemlerinin uygulamalarında kullanımına rastlanmamaktadır. Bu 
ilkelerin tümünün birlikte ortaokul seviyesinde, yedi ilkenin kapsadığı aktif öğrenme yöntemlerinden işbirlikli öğrenme yöntemi kullanılarak hayata geçirilmesi literatüre katkı sağlayacaktır.

$\mathrm{Bu}$ araştırmanın amacı 7. sınıf "Maddenin Tanecikli Yapısı Ünitesi”, "Karışımlar" konusunda işbirlikli öğrenme yönteminin yedi ilke ve modellerle öğretilmesinin öğrencilerin mikro boyuttaki kavramsal anlamalarına etkisini araştırmaktır.

\section{Yöntem}

Bu bölümde araştırmanın modeli, örneklemi, veri toplama aracı, verilerin analizi ve uygulama aşaması yer almaktadir.

\section{Araştırmanın Modeli}

Bu çalışmada nicel araştırma yöntemlerinden yarı deneysel desen kullanılmıştır.

\section{Araștırmanın Örneklemi}

Araştırmanın örneklemini 2014-2015 eğitim-öğretim y1lında Erzurum ili şehir merkezdeki bir ortaokulda 7. sınıfta öğrenim gören 58 öğrenci oluşturmaktadır. Çalışmanın yapılacağı okulun 7. sınıflarından üç şube deney grupları olarak rastgele seçilmiştir. Bu şubelerden birisi; işbirlikli öğrenmenin iyi bir eğitim ortamı için yedi ilke ve modeller ile birlikte kullanılacağı İşbirlikli Yedi İlke Model Grubu (IYYMG, n=20), ikincisi; işbirlikli öğrenmenin iyi bir eğitim ortamı için yedi ilke ile birlikte kullanılacağı İşbirlikli Yedi İlke Grubu (İYG, n=16), üçüncüsü ise işbirlikli öğrenme yöntemin kullanılacağı İşbirlikli Grup (İG, n=22) olarak seçkisiz bir şekilde belirlenmiştir.

\section{Veri Toplama Aracı}

Çalışmada, grupların uygulamalar sonunda karışımlar konusundaki kavramların tanecik boyutunda anlamalarını belirleyip karşılaştırmak için Model Çizim Testi (MÇT) kullanılmıştır. MÇT öğrencilerin mikro boyuttaki çizimlerini gerektiren açık uçlu çizim testidir. Oluşturulan taslak sorular uzman görüşünü sağlamak amacıyla iki fen eğitimcisi, bir çizim konusunda uzman öğretim üyesi ve iki fen bilimleri öğretmenine gösterilmiştir. Bu şekilde soruların kapsam geçerliliğinin sağlanması amaçlanmıştır. Pilot uygulama için MÇT 7. sınıflardan 50 öğrenciye uygulanmıştır. Soruların güvenirliği için öğrenci çizimleri 3 kimya eğitimcisi tarafından birbirinden bağımsız olarak puanlanmış ve aralarındaki tutarlılığa bakılmıştır. Alınan dönütler doğrultusunda gerekli düzeltmeler yapılan MÇT üç sorudan oluşmaktadır.

MÇT, 7. sınıf fen bilimleri dersi "Karışımlar" konusu ile ilgili tanecik boyutundaki çizimleri içermektedir. İlk soruda öğrencilerden $\mathrm{NaCl}$ 'nin suda çözünmesinin tanecik boyutunda nasıl gerçekleştiğini çizmeleri istenmiştir. Bu soruda öğrencilerden su moleküllerini $\mathrm{Na}$ iyonlarına oksijen, $\mathrm{Cl}$ iyonlarına hidrojen tarafından yaklaşıp çevreleyerek çizmeleri ve verilen kutu içerisine dağıtmaları beklenmektedir. İkinci soruda öğrencilerden şekerin suda çözünmesinin tanecik boyutunda nasıl gerçekleştiğini çizmeleri istenmiştir. Bu soruda öğrencilerden su moleküllerini şeker moleküllerine rastgele yönlerden yaklaşıp çevreleyerek çizmeleri ve verilen kutu içerisine dağıtmaları beklenmektedir. Üçüncü soruda dereceli silindirlerde $50 \mathrm{~mL}$ hacminde su ve $50 \mathrm{~mL}$ hacminde etil alkol verilmiştir. Bu su ve etil alkol $100 \mathrm{~mL}$ 'lik dereceli silindire dökülüp karıştırılmıştır. Etil alkolün su içerisinde çözünebildiği düşünüldügü̈nde öğrencilerden elde edilen çözeltinin tanecik modelini toplam hacmi düşünerek, $100 \mathrm{~mL}$ 'lik dereceli silindirin içine çizmeleri istenmiştir. Bu soruda öğrencilerden su ve etil alkol moleküllerini dereceli silindirin her yerine $100 \mathrm{~mL}$ den az olacak şekilde düzensiz ve homojen olarak dağıtmaları beklenmektedir. Araştırmada kullanılan MÇT EK’te verilmiştir.

\section{Verilerin Analizi}

Açık uçlu çizim testi olan MÇT'nin analizinde öncelikle MÇT'deki soru sayıs1 100'e bölünerek doğru çizimler için verilecek puan belirlenmiş, hatalı çizimlere ise sıfır puan verilmiştir. Elde edilen puanlar SPSS 20.0 paket programına aktarılmıştır. Verilerin çözümlenmesinde betimleyici istatistiklerden ortalama ve standart sapma, anlamlılık analizleri için ise tek yönlü varyans analizi (One Way ANOVA) kullanılmıştır. Gruplar arasında anlamlı fark çıkması durumunda çoklu karşılaştırma testlerinden LSD'den faydalanılmıştır. Daha sonra öğrenci çizimleri MÇT'deki her soru için ayrıntılı olarak incelenmiş, doğru çizimler ve benzer hatalı çizimler "doğru çizim" ve "hatalı çizim" şeklinde 
kategoriler altında toplanarak yüzdeleri (\%) hesaplanmıştır. Böylelikle gruplardaki öğrencilerin sahip oldukları yanlış anlamalar tespit edilmiş, tablolar halinde sunulmuştur. Son olarak, gruplarda bu yanlış anlamalara sahip öğrenci çizimlerinden örnekler çizimi yapan öğrencinin koduyla $\left(\ddot{\mathrm{O}}_{1}, \ddot{\mathrm{O}}_{2}, \ddot{\mathrm{O}}_{3} \ldots\right)$ birlikte olduğu gibi sergilenmiştir.

\section{Uygulama}

Gruplarda uygulamalar üç hafta sürmüştür. İG’deki uygulamada; işbirlikli öğrenmenin Öğrenci Takım Başarı Bölümleri (ÖTBB) yöntemine göre konular işlenmiştir. Yöntemin uygulanması sürecinde ilk olarak öğrenciler 4 ve 5 kişilik heterojen takımlara ayrılmıştır. Takımlardaki öğrenciler belirlendikten sonra takım üyeleri aynı masada oturtulmuş, takım isimlerini ve takım başkanlarını belirlemeleri istenmiştir. Ardından araştırmacı konuyu anlatmıştır. Daha sonra öğrenciler takımca $20 \mathrm{dk}$ konuya çalışmıştır. Öğrencilerin çalıştıkları konuyu takım olarak pekiştirmeleri için çalışma yaprakları dağıtılmıştır. Öğrenciler çalışma yaprakları üstünde grupça çalışmış, soruları birlikte tartışarak, yanıtları karşılaştırarak cevaplamış, birbirlerinin yanlışlarını düzeltmişlerdir. Öğrenciler tüm grup arkadaşlarının konuyu tam olarak öğrendiğinden emin olmuşlardır. Öğrenciler çalışma yaprağını bitirdiğinde öğretmen soruları cevaplandırmış, tüm soruları doğru cevaplayan takımlar, takım arkadaşlarıyla el sıkışarak birbirlerini tebrik etmişlerdir. Daha sonra sınav aşamasına geçilmiştir. Öğrenciler kısa bir sınavla bireysel değerlendirmeye tabi tutulmuşlardır. Takımdaki her öğrencinin aldığı sınav puanının ortalaması alınarak takım puanı bulunmuştur, en çok puan alan takım ödüllendirilmiştir.

IYY'deki uygulamada; işbirlikli öğrenmenin ÖTBB yöntemine göre, yedi ilke uygulamaları entegre edilerek konular işlenmiştir. ÖTBB yöntemin nasıl uygulandığı yukarıda İG'de yapılan uygulamaların açıklanmasında ayrıntılı anlatılmıştır. IYYG'de ÖTBB yönteminin uygulanması için yapılan çalışmalara ek olarak yedi ilkenin her ilkesinin hayata geçirilmesi adına sınıf içi ve sınıf dışı uygulamalar yapılmıştır.

Öğrenci-okul etkileşimi ilkesini gerçekleştirmek için çalışma boyunca öğrencilere isimleri ile hitap edilmiş, kendilerini yakın hissetmeleri sağlanmıştır. Öğrencilere rehber olmaya çalışılmış, sorunları ile ilgili okul idarecileri ve rehberlik servisi ile görüşülmüştür. Ayrıca veli izinleri alınmış ve öğrencilerle hafta sonu etkinlikleri düzenlenmiştir. Piknik ve sinema etkinliklerinde öğrencilerle bağlarını güçlendiren araştırmacı bu sayede öğretmen-öğrenci iletişimini geliştirmeyi hedeflemiştir. Okul bahçesinde düzenlenen piknik etkinliğine öğrencilerin diğer ders öğretmenleri ve idareciler de davet edilmiş böylece öğrencilerle iletişimlerini güçlendirmeleri sağlanmıştır.

Öğrenciler arası işbirliği ilkesini gerçekleştirmek için konunun öğretimi işbirlikli öğrenme yöntemine göre gerçekleştirilmiş bu sayede öğrenciler bilgilerini takım arkadaşları ile paylaşmışlar, birlikte projeler hazırlamışlar, sınavlara birlikte çalışmışlar ve birbirlerinin başarılarını tebrik etmişlerdir.

Aktif öğrenme ilkesini gerçekleştirmek için öğrencilere konu ile ilgili araştırma ödevleri verilmiş ve bu ödevleri derste takımca sunmaları istenmiştir. Öğrenciler proje geliştirme ve etkinlikler düzenleme konusunda teşvik edilmiştir. Konunun öğretimi bulmaca, yarışma gibi farklı teknikler ile gerçekleştirilmiş öğrencilere konu ile ilgili araştırma ödevleri verilerek ders ile günlük hayatta karşılaştıkları olayları ilişkilendirmeleri istenmiştir. Öğrencilerin öğretilen konularla ilgili farklı fikirler ortaya atmaları istenmiş, dersin işlenişi sürecine aktif olarak katılmaları sağlanmıştır.

Anlık geri bildirimler ilkesini gerçekleştirmek için öğrencilere konu ile ilgili sorular sorularak dönüt alınmış, konu sonunda kısa sınav uygulanmış ve diğer ders sınav sonuçları öğrencilere bildirilmiştir. Sınavlarındaki zayıf ve güçlü yönler bir önceki sınavları ile karşılaştırılarak öğrencilerle birlikte tartışılmış kendi başarı ve ilerlemelerini kaydetmeleri sağlanmıştır. Ayrıca verilen ödevler ve projeler en kısa sürede değerlendirilmiş sonuçları üzerinde öğrencilerle görüş alış verişi yapılmıştır.

Görevleri zamanında yapma ilkesini gerçekleştirmek için konu boyunca öğrencilere takımca konuya çalışma süreleri, ödevlerini ve projelerini teslim etme süreleri net bir şekilde belirtilmiş, verilen görevleri zamanında yapmaları için uyarılmıştırlar. Öğrencilere konuları zamanında öğrenmenin ve zamanı etkili kullanmanın önemi anlatılmıştır. Düzenli çalışma programına sahip olmayan ve görevlerini zamanında yapmayan öğrencilerle görüşülmüş sorunları çözülmeye çalışılmıştır.

Üst düzey ulaşılabilir beklentilere cevap verme ilkesini gerçekleştirmek için öğrencilere konu başında bireysel değerlendirme formları dağıtılmıştır. Konu boyunca bu kriterlere göre izlenip değerlendirilecekleri ve ulaşmaları 
beklenen başarı düzeyi açıklanmıştır. Konu boyunca sık sık öğrencilere bu hedefe ulaşmak için sıkı çalışmaları gerektiği ve akademik başarıda yüksek beklentilere sahip olmanın önemi hatırlatılmıştır. Başarılı takımların sınav puanları, projeleri ve ödev raporları panoya asılarak öğrenci başarıları çevreye duyurulmuş bu şekilde öğrenciler çalışmaya teşvik edilmiştir. Öğrencilere kişisel çalışma programları hazırlanarak kendilerine ulaşabilecekleri hedefler belirlemelerine yardımcı olunmuştur.

Farklı yetenek ve öğrenme stillerine karşı toleranslı olma ilkesini gerçekleştirmek için konu başında öğrencilere dersi nasıl işlemek istedikleri sorulmuş nasıl daha iyi öğrenebilecekleri konusunda görüş alış verişi yapılmıştır. Anlamadıkları yerleri sormaları ve nasıl öğretilmesini istediklerini rahatça söylemeleri için desteklenmişlerdir. Fazladan ve bireysel olarak çalışma yapmak isteyen öğrenciler için gerekli şartlar sağlanmıştır. Konunun öğretiminde işbirlikli öğrenme yöntemi kullanılmış, grup çalışması, okuma, yazma, proje ve yarışmalarla öğrencilerin öğrenme stillerine cevap vermeye çalışılmıştır.

IYYMG'deki uygulamada; işbirlikli öğrenmenin öğrenci takım başarı bölümleri (ÖTBB) yöntemine göre, yedi ilke uygulamaları ve model çalışmaları ile konu işlenmiştir. ÖTBB yönteminin ve yedi ilkenin nasıl uygulandığ 1 yukarıda İG ve IYYG'de yapılan uygulamaların açıklanmasında ayrıntılı anlatılmıştır. IYYMG'de ÖTBB yöntemi ve yedi ilke uygulamalarına ek olarak öğrenciler konu çalışmalarını bitirdikten sonra model çalışmaları yapmıştır. Model çalışmalarındaki amaç çözünme olayını öğrencilere tanecik boyutunda kavratmaktır. Bu amaçla model çalışmaları kapsamında iki mikro boyutu anlamaya yardımcı deney, bir boncuk modeli ve bir molekül modeli çalışması hazırlanmıştır.

1. Mürekkebin çözünme deneyi: Öğrenciler, katıların suda çözünme olayını, tuz ve şeker kristallerinin saydam olması dolayısı ile zihinlerinde somutlaştıramamaktadır. Çözünme deneyi boyar bir sıvı olan mürekkep ile yapıldığında öğrenciler çözünen maddenin su içinde nasıl dağıldığını gözlemleyebileceklerdir. Deney gösteri deneyi olarak araştırmacı tarafından yapılmıştır. Öğrencilere mürekkep taneciklerinin su tanecikleri arasında yavaş yavaş dağıldığı, bu olayın şekerin suda çözünmesi ile aynı şekilde olduğu açıklaması yapılmıştır. Mürekkep renkli bir madde olduğu için dağılmasını gözlemleyebildiğimiz söylenmiştir. Mürekkep tamamen dağıldığında oluşan karışımın sıvı sıvı homojen karışım yani çözelti olduğu açıklanmıştır. Oluşan çözelti takımlara sırayla verilerek öğrencilerin incelemesi sağlanmıştır. Aşağıda model çalışmaları kapsamında yapılan mürekkebin çözünme deneyi fotoğrafı verilmiştir (Şekil 1).

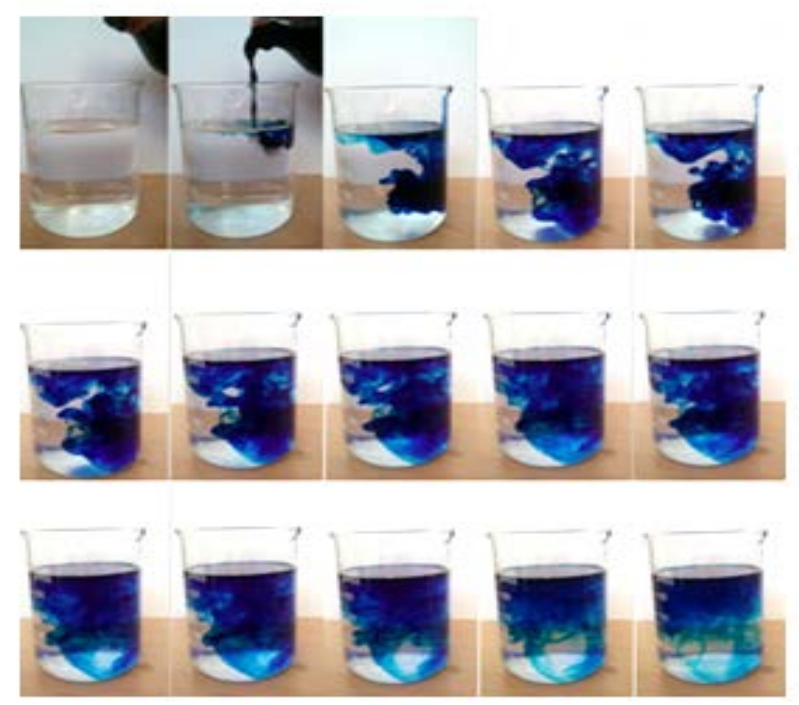

Şekil 1. Mürekkebin çözünme deneyi

2. Sıvı-Sıvı Homojen Karışım Deneyi: Öğrencilerin sıvı-sıvı homojen karışımlarda hacim azalması olayını gözleri ile görmeleri için ikinci deneye geçilmiştir. $50 \mathrm{~mL}$ 'lik iki mezürün birisi etil alkol, diğeri su ile doldurulup hacimleri öğrencilere okutulmuştur. Daha sonra ikisi de $100 \mathrm{~mL}$ 'lik bir mezüre dökülmüş ve hacmi tekrar okutulmuştur. Karışımın toplam hacminin, su ve etil alkolün hacimlerinin toplamından daha az olduğu görülmüştür. Öğrencilere bunun nedeninin iki sıvının taneciklerinin birbiri içindeki boşluklara girip dağılması olduğu açıklanmıştır. Aşağıda model çalışmaları kapsamında yapılan sıvı-sıvı homojen karışım deneyi fotoğrafı verilmiştir (Şekil 2). 


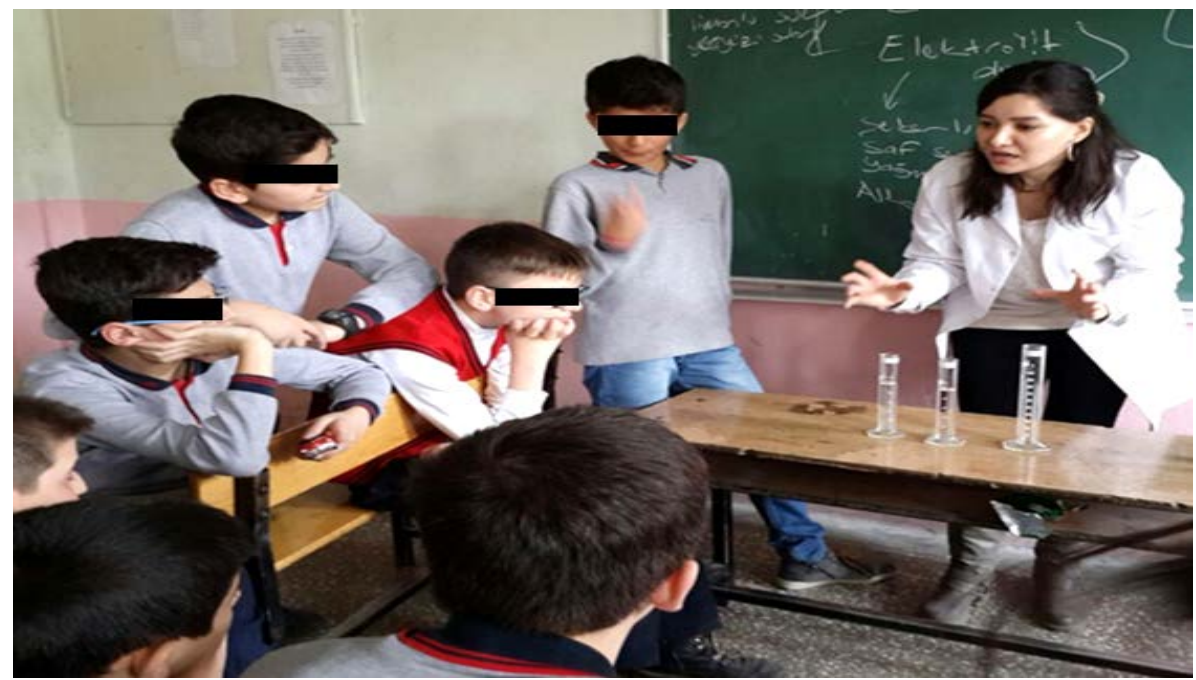

Şekil 2. Sıv1-sıvı homojen karışım deneyi

3. Boncuk Modeli Çalışması: Bu kısımda, bir önceki sıvı-sıvı homojen karışım deneyinde gösterilen toplam hacmin azalmasını boncuk modelleri ile canlandırarak tanecikleri gözle görülür hale getirip olayı öğrencilerin zihinlerinde somutlaştırmak hedeflenmiştir. Modelleme su ve etil alkol moleküllerini temsil eden farklı büyüklük ve renklerde boncuklarla yapılmıştır. Pembe büyük boncuklar etil alkol moleküllerini, sarı küçük boncuklar ise su moleküllerini temsil etmektedir. $50 \mathrm{~mL}$ 'lik mezürlere, pembe boncuklar ve sarı boncuklar ayrı ayr1 $50 \mathrm{~mL}$ seviyesine kadar doldurulmuştur. Daha sonra her iki mezürdeki boncuklar $100 \mathrm{~mL}$ 'lik başka bir mezürde birleştirilmiş, çalkalanarak karıştırılmış ve ölçümü alınmıştır. Küçük boncukların büyük boncuklar arasına girdiği ve mezürdeki seviyenin 100 mL'den az olduğu öğrenciler tarafından gözlenmiştir. Modellerle gerçeği arasındaki fark öğrencilere açılanarak modelden kaynaklanabilecek kavram yanılgılarının önüne geçilmiştir. Aşağıda model çalışmaları kapsamında yapılan boncuk modeli çalışması fotoğrafı verilmiştir (Şekil 3).

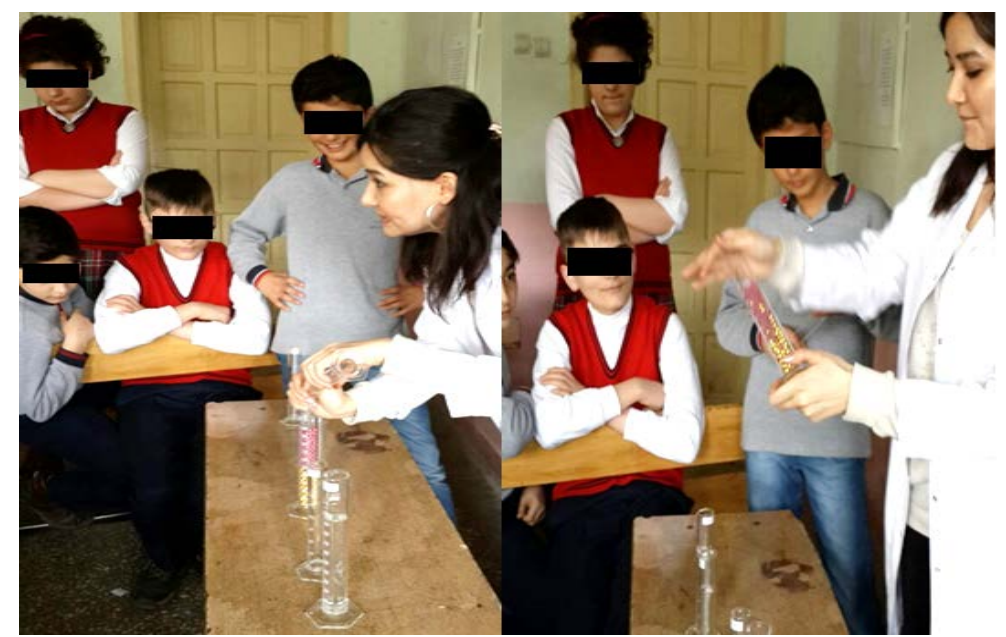

Şekil 3. Boncuk modeli çalışması

4. Molekül Modeli Çalışması: Son olarak iyonik ve moleküler yapıdaki katıların sıvı içerisindeki çözünmelerini zihinlerinde somutlaştırmaları için, öğrencilere molekül modelleriyle tuzun çözünmesi ve şekerin çözünmesi olayı yaptırılmıştır. Her takıma bir molekül modeli çantası verilmiştir. Öğrenciler modelleri takımca yapmışlardır. Tahtaya suyun, tuzun ve şekerin formülü yazılarak molekül modelleri çizilmiştir. Öğrencilerden suya atılan tuzun ve şekerin çözünüşünü modellerle göstermeleri istenmiştir. Farklı atomları farklı boncuklardan seçmeye dikkat etmeleri çünkü her boncuğun farklı elementi temsil ettiği için farklı renk ve boyutta olduğu öğrencilere hatırlatılmıştır. Modellerle gerçeği arasındaki fark öğrencilere açıklanarak modelden kaynaklanabilecek kavram yanılgılarının önüne geçilmiştir. 
Takımlar gezilerek yaptıkları modellerdeki çözünme olayını anlatmaları istenmiştir. Aşağıda model çalışmaları kapsamında yapılan molekül modeli çalışması fotoğrafları verilmiştir (Şekil 4).
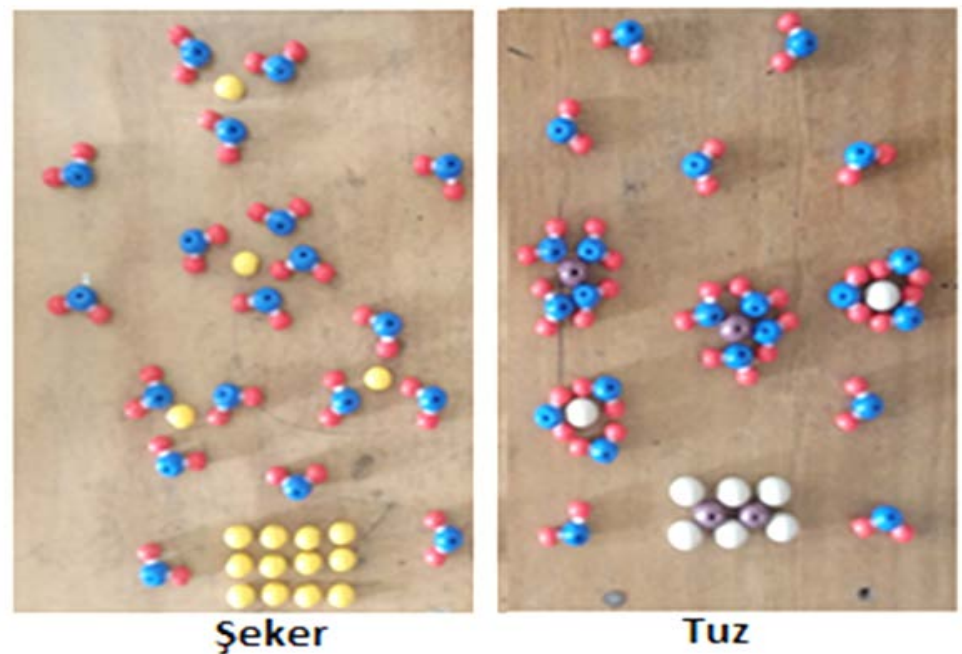

Şekil 4. Öğrencilerin molekül modeli çalışmaları

Gruplarda gerçekleştirilen çalışmalar sonunda öğrencilere MÇT uygulanmıştır.

\section{Bulgular}

IYYMG, IYYG ve İG öğrencilerinin MÇT çizimlerinden elde edilen verilerin tanımlayıcı istatistikleri ve ANOVA sonuçları Tablo 1'de sunulmuştur.

Tablo 1. MÇT’den elde edilen verilerinin tanımlayıcı istatistikleri ve ANOVA sonuçları

\begin{tabular}{|c|c|c|c|c|c|c|}
\hline Gruplar & $\mathbf{n}$ & $\mathbf{X}$ & s.s & $\mathbf{F}$ & $\mathbf{p}$ & Anlamlı Fark \\
\hline$\overline{\mathrm{I}} \mathrm{IG}$ & 22 & 47,59 & 17,07 & & & İYMG*-İG \\
\hline$\overline{\mathrm{IYYG}}$ & 16 & 65,47 & 11,70 & 53,07 & 00 & IYYMG*-IYG \\
\hline$\overline{\text { İYMG }}$ & 20 & 92,00 & 7,85 & & & IYYG*-İG \\
\hline
\end{tabular}

*:Anlamlı farkın lehine olduğu grubu gösterir.

Tablo 1'de konunun sonunda uygulanan MÇT'den alınan puanlardan en yüksek ortalamaya sahip olan grubun IYMG olduğu (X=92,00), bunu sırayla IYG $(X=65,47)$ ve İG’nin $(X=47,59)$ takip ettiği görülmektedir.

Yapılan ANOVA sonucunda gruplardaki öğrencilerin MÇT çizimleri arasında istatistiksel açıdan anlamlı bir fark tespit edilmiştir $(\mathrm{p}<, 05)$. Anlamlı farkın hangi gruplar arasında olduğunu belirlemek için yapılan LSD testi sonucunda anlamlı farkın IYMG ile İG ve IYG arasında IYMG lehine, IYG ile İG arasında ise IYYG lehine olduğu tespit edilmiştir.

Araştırma gruplarındaki öğrencilerin MÇT’nin birinci sorusu için yapmış oldukları çizimler, kategoriler altında toplanarak sahip oldukları hatalı çizimler belirlenmiş, yüzdeleri hesaplanarak Tablo 2'de sergilenmiştir.

Tablo 2'de görüldüğü gibi birinci sorunun çiziminde IYMG öğrencilerinin \%90'1 doğru çizim yapmış iken IYG'de bu oran $\% 68,8$, İG'de ise $\% 50$ olarak belirlenmiştir. Grupların sorunun bu kısmında yaptıkları hatalı çizimler sekiz kategori altında toplanmıştır. Öğrencilerin en fazla hatalı çizimi su moleküllerini birbiriyle aynı çizmeyerek yaptıkları görülmektedir.

Öğrencilerin birinci soruyla ilgili yapmış olduğu bir doğru çizim örneği Şekil 5'de, hatalı çizim örnekleri ise Şekil 6'da verilmiştir.

Şekil 5'de IYYG-Ö̈14'ün doğru çizimi görülmektedir. Öğrenci su moleküllerini $\mathrm{Na}^{+}$iyonlarına oksijen, $\mathrm{Cl}^{-}$ iyonlarına ise hidrojen tarafından yaklaştırarak çevreletmiş ve verilen kutu içerisine dağıtmıştır ayrıca farklı element atomlarını farklı çaplarda çizmiş, aynı element atomlarını aynı çap ve renkte göstermiştir. 
Tablo 2. Araştırma gruplarındaki öğrencilerin MÇT’nin birinci sorusuyla ilgili doğru ve hatalı çizimler

\begin{tabular}{|c|c|c|c|}
\hline Doğru çizim & $\begin{array}{l}\text { İYMG } \\
\%\end{array}$ & $\begin{array}{l}\text { İYG } \\
\%\end{array}$ & $\begin{array}{l}\text { İG } \\
\%\end{array}$ \\
\hline $\begin{array}{l}\text { Su moleküllerinin } \mathrm{Na}^{+} \text {iyonlarına oksijen, } \mathrm{Cl} \text { - iyonlarına hidrojen } \\
\text { tarafindan yaklaşarak çevreletilmesi }\end{array}$ & 90 & 68,8 & 50 \\
\hline \multicolumn{4}{|l|}{ Hatalı çizimler } \\
\hline Su moleküllerinin aynı çizilmemesi & - & 12,5 & 13,6 \\
\hline Atomların çaplarına dikkat edilmemesi & 5 & 12,5 & 9,1 \\
\hline Su moleküllerinin $\mathrm{Cl}^{-}$iyonlarına oksijen tarafından yaklaşması & - & - & 9,1 \\
\hline Su moleküllerinin $\mathrm{Na}^{+}$iyonlarına hidrojen tarafından yaklaşması & - & - & 9,1 \\
\hline $\begin{array}{l}\text { Su moleküllerinin tuz iyonlarının etrafını rastgele yönlerden } \\
\text { yaklaşarak çevrelemesi }\end{array}$ & - & - & 4,5 \\
\hline Tuzun iyonlarına ayrılmaması & - & 6,3 & 4,5 \\
\hline $\mathrm{Na}^{+}$iyonlarının gösterilmemesi & 5 & - & - \\
\hline Anlaşılmayan çizim & - & 6,3 & 13,6 \\
\hline
\end{tabular}

*Bazı öğrencilerin cevapları birden fazla hatalı çizim içerebilmektedir.

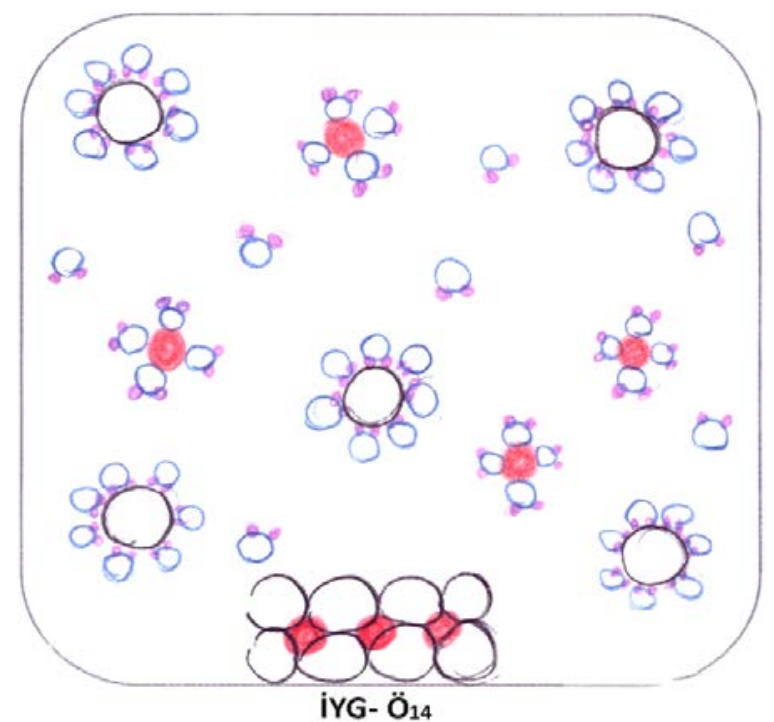

Şekil 5. Birinci soru ile ilgili doğru çizim örneği

Şekil 6'da verilen hatalı çizim örnekleri incelendiğinde, IYYG-Ös'in ve IYYG-Ö'16'nın su moleküllerini aynı çizilmediği ve atomların çaplarına dikkat etmediği, İG-Ö̈'in su moleküllerini $\mathrm{Cl}^{-}$iyonlarına oksijen tarafından yaklaştırarak çizdiği, İG-Ög'un su moleküllerini $\mathrm{Na}^{+}$iyonlarına hidrojen tarafından yaklaştırarak çizdiği, İG-Ö${ }_{3}$ 'ün su moleküllerini tuz iyonlarının etrafını rastgele yönlerden yaklaşarak çevrelettiği, İG-Ö́, ${ }_{16}$ 'nın tuzu iyonlarına ayırmadığ 1 ve atomların çaplarına dikkat etmediği, IYMMG-Ö' 'in $\mathrm{Na}^{+}$iyonlarını göstermediği görülmektedir.

Araştırma gruplarındaki öğrencilerin MÇT’nin ikinci sorusu için yapmış oldukları çizimlerinde sahip oldukları hatalı çizimler ayrı ayrı belirlenerek yüzdeleri hesaplanmış Tablo 3'te sergilenmiştir.

Tablo 3’te görüldüğü gibi ikinci sorunun çiziminde IYYMG öğrencilerinin \%90'1 doğru çizim yapmış iken IYY'de bu oran \%62,5, İG'de ise \%40,9 olarak belirlenmiştir. Grupların bu soruda yaptıkları hatalı çizimler dokuz kategori altında toplanmıştır. Öğrencilerin en fazla hatalı çizimi su moleküllerinin, şeker moleküllerinin etrafını tamamen $\mathrm{H}$ tarafından yaklaşarak çevrelemesi kategorisinde yaptıkları görülmektedir.

Öğrencilerin ikinci soruyla ilgili yapmış olduğu bir doğru çizim örneği Şekil 7'de, hatalı çizim örnekleri ise Şekil 8'de verilmiştir.

Şekil 7'de İG-Ö̈'’'nın doğru çizimi görülmektedir. Öğrenci Su moleküllerini şeker moleküllerine rastgele yönlerden yaklaştırarak çevreletmiş ve verilen kutu içerisine dağıtmıştır. Ayrıca moleküllerin büyüklüklerine dikkat etmiş, farklı element atomlarını farklı çaplarda çizmiş, aynı element atomlarını aynı çap ve renkte göstermiştir. 


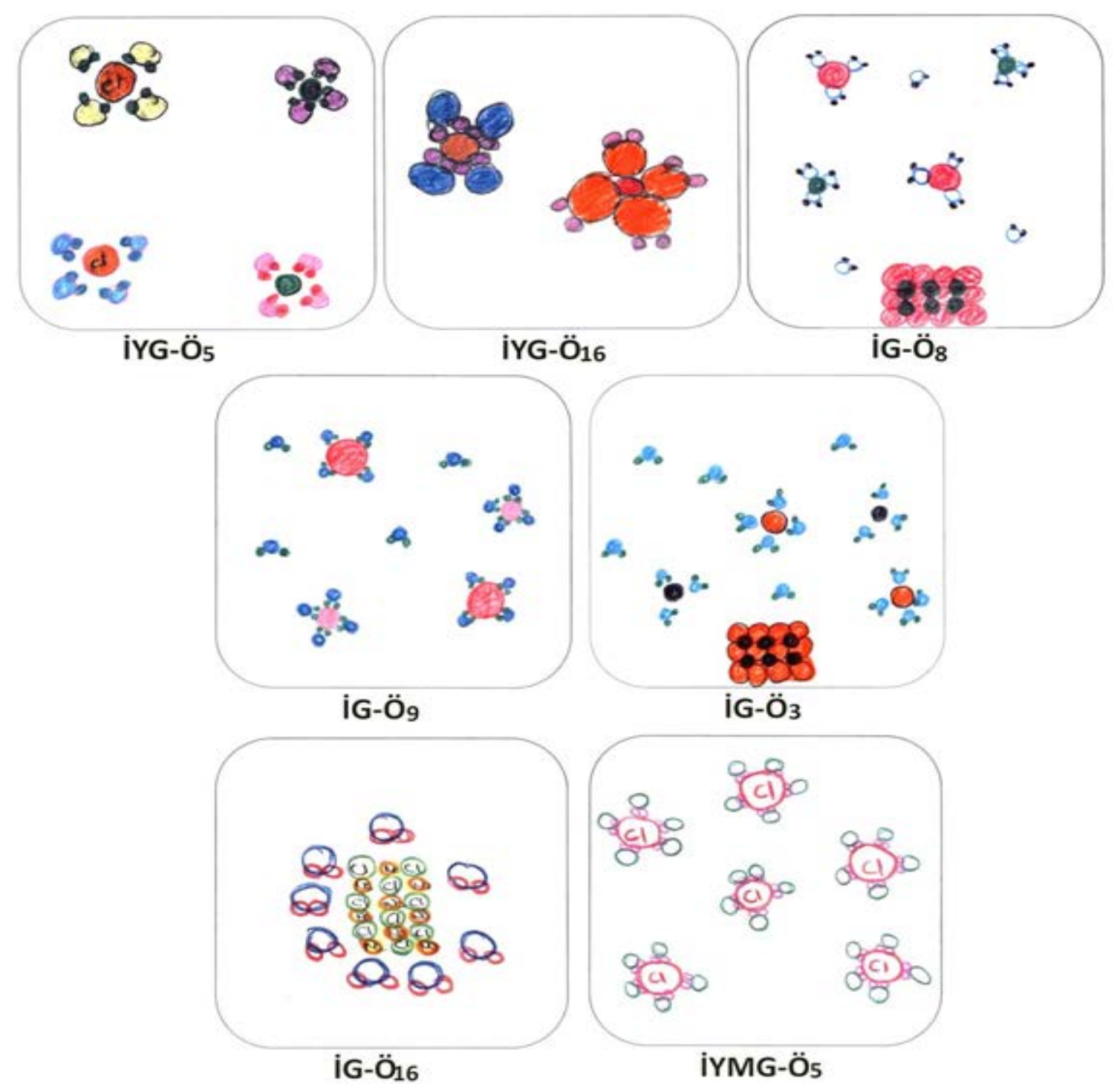

Şekil 6. Birinci soru ile ilgili hatalı çizimlerden örnekler

Tablo 3. Araştırma gruplarındaki öğrencilerin MÇT’nin ikinci sorusuyla ilgili doğru ve hatalı çizimler

\begin{tabular}{|c|c|c|c|}
\hline Doğru çizim & $\begin{array}{c}\text { IYYMG } \\
\%\end{array}$ & $\begin{array}{c}\text { İYG } \\
\%\end{array}$ & $\begin{array}{l}\text { İG } \\
\%\end{array}$ \\
\hline 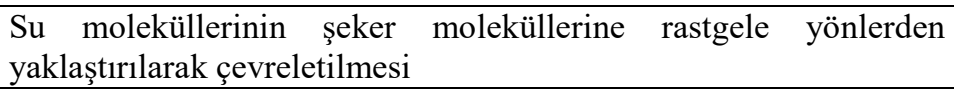 & 90 & 62,5 & 40,9 \\
\hline \multicolumn{4}{|l|}{ Hatalı çizimler } \\
\hline Yeni bir bileşik oluşturulması & - & - & 4,5 \\
\hline Șeker moleküllerinin aynı çizilmemesi & - & 12,5 & 4,5 \\
\hline Su moleküllerinin yanlış geometride çizilmesi & - & 6,3 & 9,1 \\
\hline Su moleküllerinin şeker moleküllerinin etrafinı çevrelememesi & - & - & 4,5 \\
\hline $\begin{array}{l}\text { Su moleküllerinin şeker moleküllerinin etrafını tamamen } \mathrm{H} \\
\text { tarafından yaklaşarak çevrelemesi }\end{array}$ & - & 12,5 & 13,6 \\
\hline $\begin{array}{l}\text { Su moleküllerinin şeker moleküllerinin etrafını tamamen O } \\
\text { tarafindan yaklaşarak çevrelemesi }\end{array}$ & 5 & 6,3 & 13,6 \\
\hline Sekerin iyonik yapıda cizilmesi & - & 6,3 & - \\
\hline Moleküllerin büyüklüklerine dikkat edilmemesi & 10 & 6,3 & 4,5 \\
\hline Şekerin bütünsel çizilmesi & - & - & 4,5 \\
\hline
\end{tabular}

*Bazı öğrencilerin cevapları birden fazla hatalı çizim içerebilmektedir. 


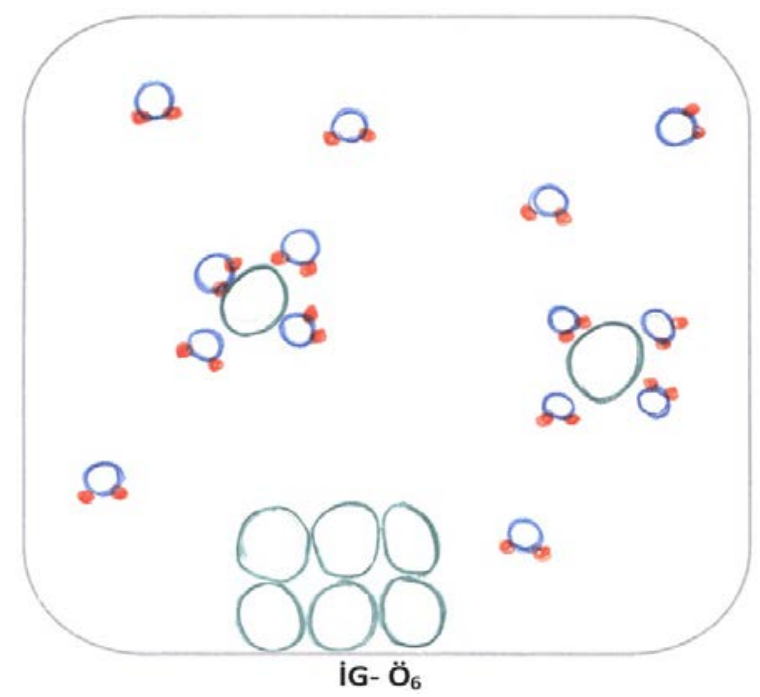

Şekil 7. İkinci soru ile ilgili doğru çizim örneği
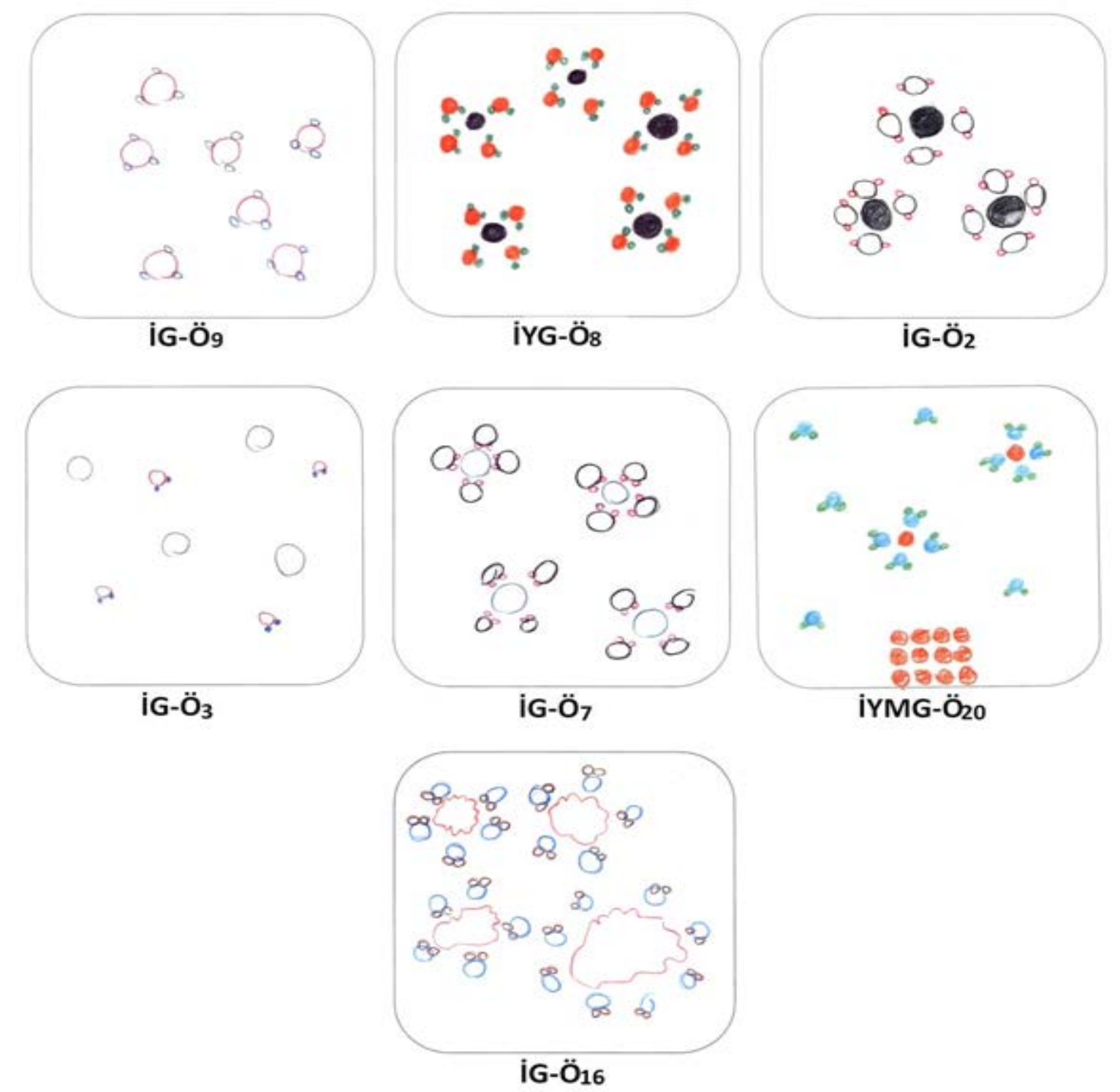

Şekil 8. İkinci soru ile ilgili hatalı çizimlerden örnekler 
Şekil 8'de verilen hatalı çizim örnekleri incelendiğinde, İG-Ög'un yeni bir bileşik oluşturduğu, IYYG-Ö,'in şeker moleküllerini aynı çizmediği, İG-Ö̈'nin su moleküllerini yanlış geometride çizdiği, İG-Ö̈'ün su moleküllerine şeker moleküllerinin etrafını çevreletmediği, İG-Ö̈'nin su moleküllerini şeker moleküllerinin etrafını tamamen H tarafından yaklaştırarak çevrelettiği, şeker moleküllerini aynı çizmediği ve moleküllerin büyüklüklerine dikkat etmediği, IYYMG-Ö ${ }_{20}$ 'nin su moleküllerini şeker moleküllerinin etrafını tamamen O tarafından yaklaşarak çevrelettiği ve moleküllerin büyüklüklerine dikkat etmediği, İG-Ö 16 'nın ise şekeri bütünsel çizdiği görülmektedir.

Araştırma gruplarındaki öğrencilerin MÇT’nin üçüncü sorusu için yapmış oldukları çizimlerinde sahip oldukları hatalı çizimler ayrı ayrı belirlenerek yüzdeleri hesaplanmış Tablo 4’te sergilenmiştir.

Tablo 4. Araştırma gruplarındaki öğrencilerin MÇT’nin üçüncü sorusuyla ilgili doğru ve hatalı çizimler

\begin{tabular}{|c|c|c|c|}
\hline Doğru çizim & $\begin{array}{c}\text { İYMG } \\
\%\end{array}$ & $\begin{array}{c}\text { İYG } \\
\%\end{array}$ & $\begin{array}{c}\text { İG } \\
\%\end{array}$ \\
\hline $\begin{array}{l}\text { Su ve etil alkol moleküllerinin dereceli silindirin her yerine } 100 \\
\text { mL'den az olacak şekilde düzensiz ve homojen olarak dağıtılması }\end{array}$ & 95 & 62,5 & 50 \\
\hline \multicolumn{4}{|l|}{ Hatalı çizimler } \\
\hline $\begin{array}{l}\text { Su moleküllerinin aynı çizilmemesi ve etil alkol moleküllerinin } \\
\text { aynı çizilmemesi }\end{array}$ & - & - & 4,5 \\
\hline Moleküllerin dereceli silindirin her yerine dağıtılmaması & - & 12,5 & 4,5 \\
\hline $\begin{array}{l}\text { Su ve etil alkol moleküllerinin dereceli silindire homojen olarak } \\
\text { dağıtılmaması }\end{array}$ & - & 6,3 & 4,5 \\
\hline $\begin{array}{l}\text { Su ve etil alkol moleküllerinin homojen fakat düzenli olarak } \\
\text { çizilmesi }\end{array}$ & 5 & - & 4,5 \\
\hline Etil alkol moleküllerinin su moleküllerinin altına çizilmesi & - & - & 4,5 \\
\hline Etil alkol moleküllerinin çizilmemesi & - & - & 4,5 \\
\hline Çözeltinin 100mL'den fazla çizilmesi & 5 & 6,3 & 4,5 \\
\hline Cözeltinin $100 \mathrm{~mL}$ çizilmesi & 5 & 25 & 22,7 \\
\hline
\end{tabular}

Tablo 4’te görüldüğü gibi üçüncü sorunun çiziminde IYYMG öğrencilerinin \%95'i doğru çizim yapmış iken IYG'de bu oran \%62,5, İG'de ise \%50 olarak belirlenmiştir. Grupların bu soruda yaptıkları hatalı çizimler sekiz kategori altında toplanmıştır. Öğrencilerin en fazla hatalı çizimi $50 \mathrm{~mL}$ 'lik etil alkol ve $50 \mathrm{~mL}$ 'lik sudan oluşacak çözeltiyi $100 \mathrm{~mL}$ olacak şekilde çizerek yaptıkları görülmektedir.

Öğrencilerin üçüncü soruyla ilgili yapmış bir doğru çizim örneği Şekil 9'da, hatalı çizim örnekleri ise Şekil 10 'da verilmiştir.

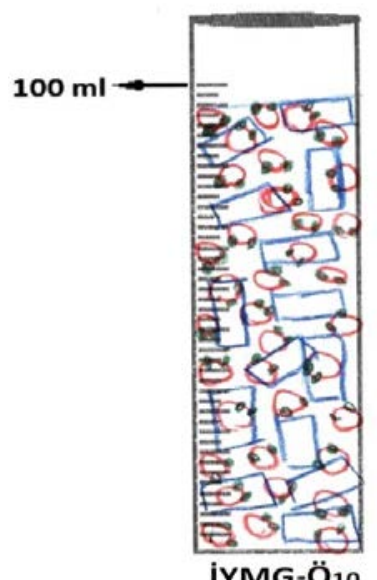

Şekil 9. Üçüncü soru ile ilgili doğru çizim örneği

Şekil 9'da İYMG-Ö'o'un doğru çizimi görülmektedir. Öğrenci su ve etil alkol moleküllerini dereceli silindirin her yerine $100 \mathrm{ml}$ den az olacak şekilde düzensiz ve homojen olarak dağıtmış ayrıca moleküllerin büyüklüklerine dikkat etmiş, farklı element atomlarını farklı çaplarda çizmiş ve aynı element atomlarını aynı çap ve renkte göstermiştir. 

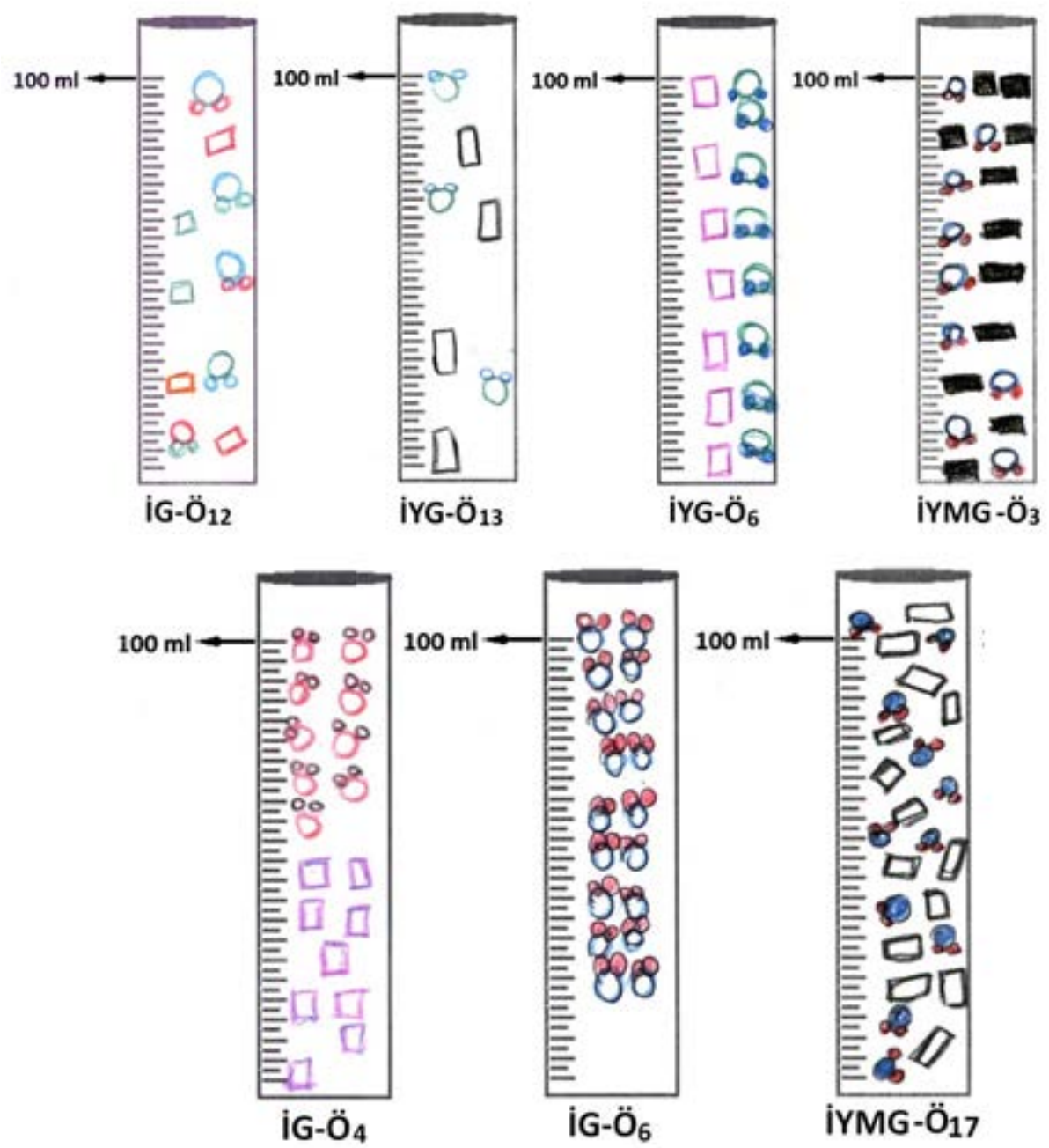

Şekil 10. Üçüncü soru ile ilgili hatalı çizimlerden örnekler

Şekil 10'da verilen hatalı çizim örnekleri incelendiğinde, İG-Ö̈' ${ }_{12}^{\prime}$ nin su moleküllerini aynı çizmediği, etil alkol moleküllerini aynı çizmediği ve çözeltiyi $100 \mathrm{~mL}$ çizdiği, IYYG-Ö ${ }_{13}^{\prime}$ ün molekülleri dereceli silindirin her yerine dağıtmadığı ve çözeltiyi $100 \mathrm{~mL}$ çizdiği, IYG-Ö̈'nın su ve etil alkol moleküllerini dereceli silindire homojen olarak dağıtmadığı ve çözeltiyi $100 \mathrm{~mL}$ çizdiği, IYYMG-Ö̈'ün su ve etil alkol moleküllerini homojen fakat düzenli olarak çizdiği ve çözeltiyi $100 \mathrm{~mL}$ çizdiği, İG-Ö,'ün etil alkol moleküllerini su moleküllerinin altına çizdiği ve çözeltiyi $100 \mathrm{~mL}$ 'den fazla çizdiği, İG-Ö̈'nın etil alkol moleküllerini çizmediği, molekülleri dereceli silindirin her yerine dağıtmadığ 1 ve çözeltiyi $100 \mathrm{~mL}$ 'den fazla çizdiği, IYYMG-Ö 17 'nin çözeltiyi $100 \mathrm{~mL}$ 'den fazla çizdiği görülmektedir.

\section{Tartışma, Sonuç ve Öneriler}

"Karışımlar" konusu ile ilgili hazırlanan MÇT için araştırma grubu öğrencilerinin çizimleri karşıllaştırıldığında, İYMG öğrencileri ile IYYG ve İG öğrencileri arasında IYMG lehine, IYYG öğrencileri ile İG öğrencileri arasında IYYG öğrencileri lehine anlamlı fark tespit edilmiştir. Buradan IYYMG öğrencilerinin diğer araştırma grubu öğrencilerine göre, IYG öğrencilerinin ise İG öğrencilerine göre konuyu mikro boyuttaki anlamalarının daha iyi olduğu anlaşılmaktadır. Dolayısıyla model çalışmalarının ve yedi ilkenin, işbirlikli öğrenme yöntemi ile uygulanmasının konuyla ilgili mikro boyuttaki anlamaları artırdığı söylenebilir.

Yedi ilkenin öğrencilerin konu ile ilgili mikro boyuttaki anlamalarını artırmasının nedeni yedi ilkenin tümünün birlikte hayata geçirilerek konunun öğretimi sürecine entegre edilmesi olduğu düşünülmektedir. Eğitim sürecinin tüm aşamalarında yedi ilkenin öğrencileri öğrenmeye teşvik ettiği, öğrenciler arasındaki işbirliğini arttırdığı, aktif öğrenme yöntemlerinin kullanılmasını sağladığı, anında geribildirim sağladığı, öğrencilerin yüksek düzey beklentilerine cevap verdiği ve farklı ilgi ve yeteneklere sahip öğrencilerin öğrenmesini kolaylaştırdığı birçok 
çalışmada belirlenmiştir (Aydoğdu, 2012; Bishoff, 2010; Donovan \& Loch, 2013; Wang, Doll, Deng, Park, \& Yang, 2013). Ayrıca yedi ilke uygulamalarının işbirlikli öğrenme yöntemini desteklediği yapılan çalışmalara da ortaya konmuştur (Çavdar \& Doymuş, 2016; Okumuş, Öztürk, Koç, Çavdar, \& Aydoğdu, 2013). Buradan hareketle yedi ilkenin hayata geçirilme çalışmalarında yöntem olarak işbirlikli öğrenmenin seçilmesinin isabetli olduğu söylenebilir.

Modellerin öğrencilerin konu ile ilgili mikro boyuttaki anlamalarını artırmasının nedeni, modellerin öğrencilere dokunarak deneyimleme firsatı vermesi, birden çok duyu organına hitap etmesi dolayısıyla soyut kavramları öğrencilerin zihinlerinde somutlaştırması ve eğlenerek öğrenmelerini sağlaması olduğu düşünülmektedir. Modellerin karışımlar konusunda öğrencilerin kavramsal anlamalarını artırdığı Minaslı (2009)'nın çalışmasında da tespit edilmiştir.

İlk soruda öğrencilerin tuzun suda çözünmesinin tanecik boyutunda nasıl gerçekleştiği ile ilgili çizimleri incelendiğinde öğrencilerin, su moleküllerinin aynı çizilmemesi, atomların çaplarına dikkat edilmemesi, su moleküllerinin klor iyonlarına oksijen tarafından yaklaşması, su moleküllerinin sodyum iyonlarına hidrojen tarafından yaklaşması, su moleküllerinin tuz iyonlarının etrafını rastgele yönlerden yaklaşarak çevrelemesi, tuzun iyonlarına ayrılmaması, sodyum iyonlarının gösterilmemesi şeklinde hatalı çizimler yaptıkları belirlenmiştir.

İkinci soruda öğrencilerin şekerin suda çözünmesinin tanecik boyutunda nasıl gerçekleştiği ile ilgili çizimleri incelendiğinde öğrencilerin, yeni bir bileşik oluşturulması, şeker moleküllerinin aynı çizilmemesi, su moleküllerinin yanlış geometride çizilmesi, su moleküllerinin şeker moleküllerinin etrafinı çevrelememesi, su moleküllerinin şeker moleküllerinin etrafını hidrojen tarafından yaklaşarak çevrelemesi, su moleküllerinin şeker moleküllerinin etrafını oksijen tarafından yaklaşarak çevrelemesi, şekerin iyonik yapıda çizilmesi, moleküllerin büyüklüklerine dikkat edilmemesi, şekerin bütünsel çizilmesi şeklinde hatalı çizimler yaptıkları belirlenmiştir. Şekerin suda iyonlarına ayrılarak çözüneceği yanılgısı Çalık (2006)'ın çalışmasında da tespit edilmiştir. Ayrıca literatürde de öğrencilerin maddenin bütünsel olduğunu düşündükleri çalışmalar mevcuttur (Ayas \& Özmen, 2002; Köseoğlu, Atasoy, Kavak, Akkuş, Budak, \& Tumay, 2003; Say, 2011). Diğer taraftan öğrencilerin çözünme olayını kimyasal bir değişim gibi düşünerek yeni bir bileşik oluşturmaları yani çözünen maddenin yeni bir maddeye dönüştüğü yanılgısıyla literatürde sık karşılaşılmaktadır (Çalık, 2006; Demircioğlu, Altuntaş-Aydın, \& Demircioğlu, 2012; Okumuş, Öztürk, Doymuş, \& Alyar, 2014; Özalp, 2008; Saydam, 2013).

Uluçınar Sağır, Tekin ve Karamustafaoğlu (2013) ile Okumuş, Çavdar ve Doymuş (2015)'un araştırmalarında da öğrencilerin iyonik ve moleküler çözünmeyi tam olarak anlamadıkları belirlenmiştir.

MÇT’nin üçüncü sorusunda dereceli silindirlerde $50 \mathrm{~mL}$ hacminde su ve $50 \mathrm{~mL}$ hacminde etil alkol verilmiştir. $\mathrm{Bu}$ su ve etil alkol $100 \mathrm{~mL}$ lik dereceli silindire dökülüp karıştırılmıştır. Etil alkolün su içerisinde çözünebildiği düşünüldüğünde öğrencilerden elde edilen çözeltinin tanecik modelini toplam hacmi düşünerek $100 \mathrm{~mL}$ lik dereceli silindirin içine çizmeleri istenmiştir. Soru ile ilgili çizimler incelendiğinde öğrencilerin, su moleküllerinin aynı çizilmemesi ve etil alkol moleküllerinin aynı çizilmemesi, moleküllerin dereceli silindirin her yerine dağıtılmaması, su ve etil alkol moleküllerinin dereceli silindire homojen olarak dağıtılmaması, su ve etil alkol moleküllerinin homojen fakat düzenli olarak çizilmesi, etil alkol moleküllerinin su moleküllerinin altına çizilmesi, etil alkol moleküllerinin çizilmemesi, çözeltinin $100 \mathrm{~mL}$ den fazla çizilmesi, çözeltinin 100ml çizilmesi şeklinde hatalı çizimler yaptıkları belirlenmiştir. Çözünme olayında taneciklerin homojen olarak dağıtılmaması Demircioğlu, Demircioğlu ve Ayas (2004), Raviolo (2001), Okumuş vd. (2015) ve Okumuş vd. (2014) çalışmalarında da tespit edilmiştir.

Çalışma kapsamında "Karışımlar" konusunun öğretiminde işbirlikli öğrenme yöntemi ile beraber yedi ilke ve modellerin kullanılması önerilmektedir. Ayrıca ortaokullarda etkili model kullanımının yaygınlaşması için, modelle öğretimin öğrenmeye etkisini ortaya çıkaracak araştırmalar yapılmalı, elde edilecek bulgulara göre öğretmenler model geliştirmeye, bu modelleri sınıflarında kullanmaya ve öğrencilerin zihinlerindeki modelleri ortaya çıkarmaya yönelik düzenlenecek hizmet içi eğitimlerde bilgilendirilmelidir. 


\section{Extended Summary}

\section{Introduction}

Chemistry subjects in science course contain many abstract concepts, which makes it difficult for students to develop adequate understanding. On the other hand, concepts such as atom, molecule, element, compound will be the basis for the future classes and the university for the students. For this reason, misunderstandings that may arise in secondary schools may make it difficult to learn new topics and concepts in later classes. Reinventing the subjects and making them more entertaining is of great importance in terms of avoiding these comprehension problems. The use of the models associated with the subject is an effective and fun way of making meaningful and easy learning by embodying abstract concepts in the mind. Modeling the theoretical knowledge ensures that even the most complex events can be taught / learned easily. It is important to teach the atoms, molecules, theoretical concepts modeling in order to fully and correctly understand the events at micro level. Students simply forget what they only hear. However, a teaching activity in which they themselves participate provides a better understanding of what they are doing. In this context, active learning approaches should be used in order to learn the particulate nature of matter in depth and permanently. Cooperative learning, project-based learning, probing-based learning and inquiry-based learning methods are proposed as active learning methods for understanding the chemistry at three levels (macroscopic, microscopic and symbolic). The application of collaborative learning together with models from these methods facilitates the students' conceptual understanding. Collaborative learning is an effective method for students to understand the difficulties of understanding chemistry.

Chickering and Gamson (1987) summed up a good educational environment under seven principles. These seven principles are "good practice encourages student - faculty contact", "good practice encourages cooperation among students”, "good practice encourages active learning”, "good practice gives prompt feedback”, "good practice emphasizes time on task", "good practice communicates high expectations" and "good practice respects diverse talents and ways of learning”. Chickering and Gamson (1987) state that the seven principals that provide a good learning environment with active learning methods must be implemented in the training process to enhance the effectiveness of active learning methods. Indeed, active learning and cooperation are among the principles of the seven principles. All of these principles will contribute to the literacy of co-learning at the secondary school level, using the collaborative learning method out of the active learning methods covered by the seven principles.

\section{Purpose}

The aim of this study was examining the effect of teaching the subject of Mixtures at $7^{\text {th }}$ grade with cooperative learning methodology, seven principles and models to students' conceptual understanding at micro level.

\section{Method}

Quasi-experimental design was used in quantitative research methods and determined three experiment groups. In Cooperative Seven Principles Model Group (CSPMG), seven principles for good practice and models were used with cooperative learning method, in Cooperative Seven Principles Group (CSPG), seven principles for good practice were used with cooperative learning method and in Cooperative Group (CG), cooperative learning method in teaching the subjects.

\section{Samples}

The research sample consisted of 58 students studying in 3 different class at $7^{\text {th }}$ grade.

\section{Data Collection Tool}

In the study, it was prepared Model Drawing Tests (MDT) for determining students' conceptual understanding in micro level and compare the groups. MDT is open-ended tests require students' drawings in micro level. The tests which validity and reliability analysis were performed were applied in the end of the study. MDT consists of three questions related to subject of mixtures. In the first question, students are asked to draw how $\mathrm{NaCl}$ dissolves in water 
at micro level. In the second question, students are asked to draw how sugar water dissolves at micro level. In the third step, $50 \mathrm{~mL}$ of water and $50 \mathrm{~mL}$ of ethyl alcohol which in graduated cylinders.were given to the students. This water and ethyl alcohol were poured into a $100 \mathrm{~mL}$ graduated cylinder and mixed. When it is thought that ethyl alcohol can be dissolved in water, students are asked to draw the particle model of the solution into a $100 \mathrm{~mL}$ graduated cylinder considering the total volume.

\section{Data Analysis}

In data analysis, firstly the point which was given for the correct drawings was determined by dividing the number of questions into 100. The incorrect drawings were given zero points. For the analysis of data, mean, standard deviation of descriptive statistics, One Way ANOVA of significance analyzes were used. LSD multiple comparison test was used in the event of a significant difference among the groups. After than student drawings were examined in detail for each questions in the MDT. The correct drawings and the similar incorrect drawings were divided into categories as "correct drawing” and "incorrect drawings" and calculated their percentages.

\section{Findings and Discussion}

Comparing the drawings of the students in the research groups for the MDT prepared related to the subject of mixtures, a significant difference was found in favor of IYG, between IYG and IG, and between IYG and IG in favor of IYG.

In the first question, students are asked to draw how $\mathrm{NaCl}$ dissolves in water at micro level. Students made mistaken drawings in this question that water molecules are not drawn in the same, not paying attention to the diameters of atoms, water molecules approaching chlorine ions by oxygen's side, water molecules approaching sodium ions by hydrogen's side, water molecules surround the salt ions in random directions, not separating salt into its ions, not showing sodium ions.

In the second question, students are asked to draw how sugar water dissolves at micro level. It is determined that the students made incorrect drawings in this questions such as creation of a new compound, the same drawing of sugar molecules, the drawing of water molecules in the wrong geometry, the water molecules not encircling the sugar molecules, the water molecules are surrounded around the sugar molecules by hydrogen molecules' side, the water molecules are surrounded around the sugar molecules by the oxygen molecules' side, drawing of sugar in ionic structure, not to pay attention to the size of the molecules, holistic drawing of sugar. There are also studies in the literature that students think that matter is holistic. On the other hand, it is common in the literature that students create a new compound by thinking of dissolution as a chemical change, that is, the dissolution of a substance into a new substance.

In the third question of the MDT, $50 \mathrm{~mL}$ of water and $50 \mathrm{~mL}$ of ethyl alcohol were added to the cylinders. This water and ethyl alcohol are poured into a $100 \mathrm{~mL}$ graduated cylinder and mixed. When it is thought that ethyl alcohol can be dissolved in water, it is required to draw the particle model of the solution obtained from the students into a $100 \mathrm{~mL}$ graduated cylinder considering the total volume. It is determined that the students made incorrect drawings in this questions such as water molecules are not drawn the same andand ethyl alcohol molecules are not drawn, water and ethyl alcohol molecules are not homogeneously distributed all around the graduated cylinder, water and ethyl alcohol molecules are drawn homogeneously but regularly, the drawing of ethyl alcohol molecules under water molecules, ethyl alcohol molecules are not drawn, drawing solition $100 \mathrm{~mL}$, drawing solition over $100 \mathrm{~mL}$.

\section{Conclusion}

It is understood that the students in IYMG are better than the students of the other research groups, and the students in IYG are better at micro level than the students in IG. Therefore, it can be said that the model studies and the application of the seven principles with the cooperative learning method increase the understanding in the related to the subject at micro level.

It is thought that the reason why the seven principles increase the students' understanding of the subject at micro level is that all seven principles are integrated together into the teaching process of the subject by passing it together. 
It is thought that models increase the students' understanding at the micro level of the subject, that the models appeal to more than one sensory organ because they touch the students by touching them, so they abstract the concepts into the minds of the students and learn by amusing.

In the scope of the study, it is suggested to use seven principles and models together with cooperative learning method in the teaching of mixtures subject. Furthermore, in order to promote the use of models effectively in middle schools, researches should be done to reveal the effect of learning by model. According to findings, teachers should be informed about the in-service trainings to develop models, to use these models in their classes and to reveal the models in students' minds. 


\section{Kaynakça / References}

Acar, B., \& Tarhan, L. (2008). Effects of cooperative learning on students' understanding of metallic bonding. Research in Science Education, 38, 401-420.

Adadan, E. (2014). Model-tabanlı öğrenme ortamının kimya öğretmen adaylarının maddenin tanecikli yapısı kavramını ve bilimsel modellerin doğasını anlamaları üzerine etkisinin incelenmesi. OMÜ Eğitim Fakültesi Dergisi, $33(2), 378-403$.

Ayas, A., \& Özmen, H. (2002). A study of students' level of understanding of the particulate nature of matter at secondary school level. Boğaziçi Üniversitesi Ĕ̈itim Dergisi, 19(2), 45-60.

Aydeniz, M., \& Kotowsk, E. L. (2012). What do middle and high school students know about the particulate nature of matter after instruction? Implications for practice. School Science and Mathematics, 112(2), 59-65.

Aydoğdu, S. (2012). Üniversite öğretim elemanlarının Chickering ve Gamson öğrenme ilkelerini kullanma düzeyleri (Yayımlanmamış yüksek lisans tezi). Atatürk Üniversitesi, Erzurum.

Balım, A. G., \& Ormancı, Ü. (2012). İlköğretim öğrencilerinin "Maddenin Tanecikli Yapısı" ünitesine yönelik anlama düzeylerinin çizim yoluyla belirlenmesi ve farklı değişkenlere göre analizi. Eğitim ve Öğretim Araştırmaları Dergisi, 1(4), 255-265.

Barbosa, R., Jofili, Z., \& Watts, M. (2004). Cooperating in constructing knowledge: case studies from chemistry and citizenship. International Journal of Science Education, 26, 935-949.

Bishoff, J. P. (2010). Utilization of the seven principles for good practice in undergraduate education in general chemistry by community college instructors (Unpublished doctoral dissertation). University of West Virginia, West Virginia, USA.

Chickering, A. W., \& Gamson, Z. (1987). Seven principles of good practice in undergraduate education. AAHE Bulletin, 39(7), 37.

Collard, T. Y. (2009). An investigation of the use and implementation of the seven principles for good practice in undergraduate education by university faculty members (Unpublished doctoral dissertation), Union University, Jackson, Tenesse, USA.

Cuevas, P., Lee, O., Hart, J., \& Deaktor, R. (2005). Improving science inquiry with elementary students of diverse backgrounds. Journal of Research in Science Teaching, 42(3), 337-357.

Çalık, M. (2006). Bütünleştirici öğrenme kuramına göre lise 1 çözeltiler konusunda materyal geliştirilmesi ve uygulanması (Yayımlanmamış doktora tezi). Karadeniz Teknik Üniversitesi, Trabzon.

Çavdar, O., \& Doymuş, K. (2016). Fen ve teknoloji dersinde işbirlikli öğrenme yönteminin iyi bir eğitim ortamı için yedi ilke ve modellerle kullanilması. Ĕgitimde Kuram ve Uygulama, 12(3), 741-768.

Çavdar, O., Okumuş, S., Alyar, M., \& Doymuş, K. (2016). Maddenin tanecikli yapısının anlaşılmasına farklı yöntemlerin ve modellerin etkisi. Erzincan Üniversitesi Eğitim Fakültesi Dergisi, 18(1), 555-592.

Demircioğlu, G., Altuntaş-Aydın, M., \& Demircioğlu, H. (2012). Kavramsal değişim metninin ve üç boyutlu modelin 7. sınıf öğrencilerinin atomun yapısını anlamalarına etkisi. Bayburt Üniversitesi Eğitim Fakültesi Dergisi, 7(2), 70-96.

Demircioğlu, H., Demircioğlu, G., \& Ayas, A. (2004). Sınıf öğretmeni adaylarının bazı temel kimya kavramlarını anlama düzeyleri ve karşılaşılan yanılgılar. Hasan Ali Yücel Eğitim Fakültesi Dergisi, 1, 29-49.

Demircioğlu, H., Demircioğlu, G., Ayas, A., \& Kongur, S. (2012). Onuncu sınıf öğrencilerinin fiziksel ve kimyasal değişme kavramları ile ilgili teorik ve uygulama bilgilerinin karşılaştırılması. Türk Fen Ĕ̈itimi Dergisi, 9(1), 162-181.

Donovan, D., \& Loch, B. (2013). Closing the feedback loop: Engaging students in large first-year mathematics test revision sessions using pen-enabled screens. International Journal of Mathematical Education in Science and Technology, 44(1), 113.

Doymuş, K., Karaçöp, A., \& Şimşek, Ü. (2010). Effects of jigsaw and animation techniques on students' understanding of concepts and subjects in electrochemistry. Education Tech Research Dev, 58, 671-691.

Doymuş, K., Şimşek, Ü., \& Karaçöp, A. (2009). The effects of computer animations and cooperative learning methods in micro, macro and symbolic level learning of states of matter. Eurasian Journal of Educational Research, 36, 109-128. 
Ebenezer, J. (2001). A hypermedia environment to explore and negotiate students' conceptions, animation of the solution process of table salt. Journal of Science Education and Technology, 10, 73-91.

Ergün, A. (2013). Atom ve molekül konusunda kavram yanılgıları ve bunları iyileştirmek için örnek etkinlikler (Yayımlanmamış doktora tezi). Gazi Üniversitesi, Ankara.

Friedler, Y., \& Tamır, P. (1990). Life in science laboratory classroom at secondary level: The student laboratory and the science curriculum. London: Routledge.

Karaçöp, A., \& Doymuş, K. (2012). Effects of jigsaw cooperative learning and animation techniques on students’ understanding of chemical bonding and their conceptions of the particulate nature of matter. Journal of Science Education Technology, 22(2), 186-203.

Karagöz, Ö., \& Sağlam-Arslan, A. (2012). İlköğretim öğrencilerinin atomun yapısına ilişkin zihinsel modellerinin analizi. Türk Fen Ĕ̈itimi Dergisi, 9(1), 132-142.

Koştur, H. İ, (2009). “Maddenin Tanecikli Yapısı” ünitesindeki kavramların anlama düzeylerinin incelenmesi (Yayımlanmamış yüksek lisans tezi). Başkent Üniversitesi, Ankara.

Köseoğlu, F., Atasoy, B., Kavak, N., Akkuş, H., Budak, E., \& Tumay, H. (2003). Bir fen ders kitabı nasıl olmalıdır? Ankara: Asil yayın dağıtım.

Küçükahmet, L. (2000). Öğretimde planlama ve değerlendirme (11. baskı). Ankara: Nobel Yayın Dağıtım.

Meijer, M. R. (2011). Macro-meso-micro thinking with structure-property relations for chemistry education: An explorative design-based study. Utrecht: Freudenthal Institute for Science and Mathematics Education.

Meşeci, B., Tekin, S., \& Karamustafaoğlu, S. (2013). Maddenin tanecikli yapısıyla ilgili kavram yanılgılarının tespiti. Dicle Üniversitesi Sosyal Bilimler Enstitüsü Dergisi, 5(9), 20-40.

Minaslı, E. (2009). Fen ve teknoloji dersi maddenin yapısı ve özellikleri ünitesinin ögretilmesinde simülasyon ve model kullanılmasının başarıya, kavram ögrenmeye ve hatırlamaya etkisi (Yayımlanmamış yüksek lisans tezi). Marmara Üniversitesi, İstanbul.

Nakiboğlu, C. (2001). "Maddenin yapısı" ünitesinin işbirlikli öğrenme yöntemi kullanılarak kimya öğretmen adaylarına öğretilmesinin öğrenci başarısına etkisi. G. Ü. Gazi Eğitim Fakültesi Dergisi, 21, 131-143.

Okumuş, S., Çavdar, O., \& Doymuş, K. (2015). Çözeltilerin iletkenliği yardımıyla maddenin tanecikli yapısının anlaşılması. Amasya Eğitim Fakültesi Dergisi, 4(2), 220-245.

Okumuş, S., Öztürk, B., Doymuş, K., \& Alyar, M. (2014). Maddenin tanecikli yapısının mikro ve makro boyutta anlaşılmasının sağlanması. Ĕgitim Bilimleri Araştırmaları Dergisi, 4(1), 349-368.

Okumuş, S., Öztürk, B., Koç, Y., Çavdar, O., \& Aydoğdu, S. (2013). İşbirlikli öğrenme modeli ve iyi bir eğitim için yedi ilkenin sinıfta birlikte uygulanmasi. Ekev Akademi Dergisi, 57, 493-502.

Özalp, D. (2008). İlköğretim ve ortaöğretim öğrencilerinin maddenin tanecikli yapısı konusundaki kavram yanılgılarının ontoloji temelinde belirlenmesi (Yayımlanmış yüksek lisans tezi). Marmara Üniversitesi, İstanbul.

Özmen, H., \& Ayas, A. (2003). Students’ difficulties in understanding of the conservation of the matter in open and closed-system chemical reactions. Chemistry Education: Research and Practice, 4, 279-290.

Papageorgiou, G., Stamovlasis, D., \& Johnson, P. M. (2010). Primary teachers’ particle ideas and explanations of physical phenomena: Effect of an in-service training course. International Journal of Science Education, 32(5), 629-652.

Philipp, S. B., Johnson, D. K., \& Yezierski, E. J. (2014). Development of a protocol to evaluate the use of representations in secondary chemistry instruction. Chemistry Education: Research and Practice, 15, 777-786.

Raviolo, A. (2001). Assessing students' conceptual understanding of solubility equilibrium. Journal of Chemical Education, 78, 629-631. 
Sadıç, A., \& Çam, A. (2012). İlköğretim öğrencilerine katılarda ve sıvılarda genleşmeyi gösteren alternatif modeller. Araştırma Temelli Etkinlik Dergisi (ATED), 2(2), 53-63.

Sarıkaya, R., Selvi, M., \& Doğan-Bora, N. (2004). Mitoz ve mayoz bölünme konularının öğretiminde model kullanımının önemi. Kastamonu Ĕgitim Dergisi, 12(1), 85-88.

Say, F. S. (2011). Kavram karikatürlerinin 7. sınıf ögrencilerinin "Maddenin Yapısı ve Özellikleri” konusunu ögrenmelerine etkisi (Yayımlanmış yüksek lisans tezi). Karadeniz Teknik Üniversitesi, Trabzon.

Saydam, Ö. E. (2013). Fen bilimleri ögretmen adaylarının maddenin tanecikli yapısı konusu ile ilgili kavram yanılgıları (Yayımlanmış yüksek lisans tezi). Abant İzzet Baysal Üniversitesi, Bolu.

Shachar, H., \& Fischer, S. (2004). Cooperative learning and the achievement of motivation and perceptions of students in 11th grade chemistry classes. Learning and Instruction, 14, 69-87.

Uluçınar Sağır, Ş., Tekin, S., \& Karamustafaoğlu, S. (2013). Sınıf öğretmeni adaylarının bazı kimya kavramlarını anlama düzeyleri. Dicle Üniversitesi Ziya Gökalp Ĕ̆itim Fakültesi Dergisi, 19, 112-135.

Wang, J., Doll, W. J., Deng, X., Park, K., \& Yang, M. (2013). The impact of faculty perceived reconfigurability of learning management systems on effective teaching practices. Computers \& Education, 61, 146-157. 
EK. Model Çizim Testi (MÇT)

1. Aşağıda verilen kutunun içine tuzun suda çözünmesinin tanecik boyutunda nassl gerçekleştiğini çiziniz (Aşağıda su ve tuzun tanecik modelleri verilmiştir, renkli kalemleri gerekli gördüğünüz şekilde kullanabilirsiniz).

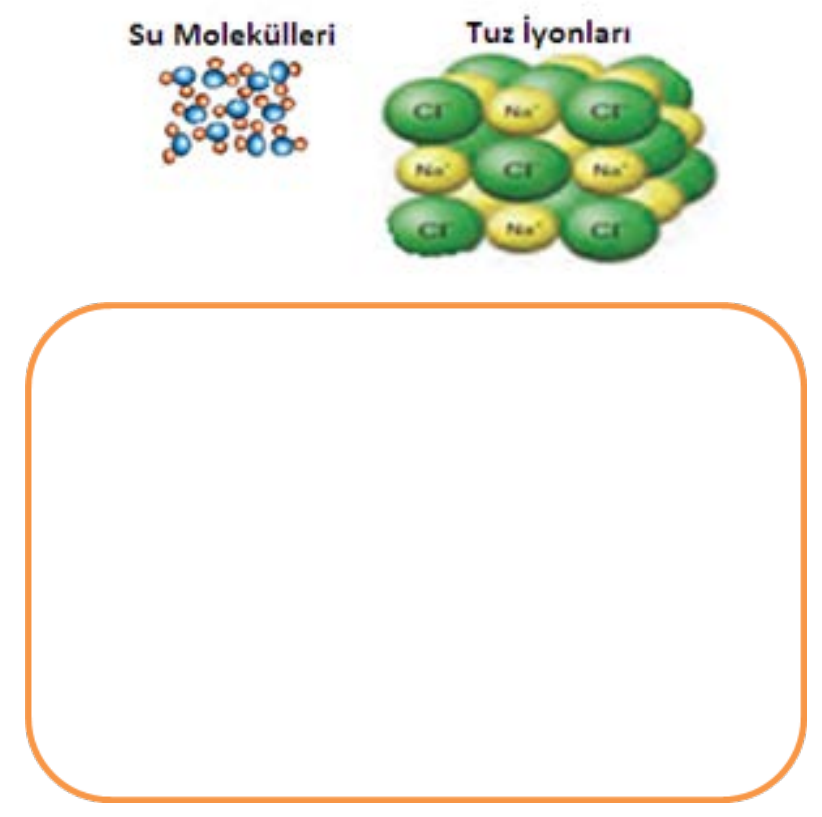

2. Aşağıda verilen kutunun içine şekerin suda çözünmesinin tanecik boyutunda nassı gerçekleştiğini çiziniz (Aşağıda su ve şekerin tanecik modelleri verilmiştir, renkli kalemleri gerekli gördüğünüz şekilde kullanabilirsiniz).
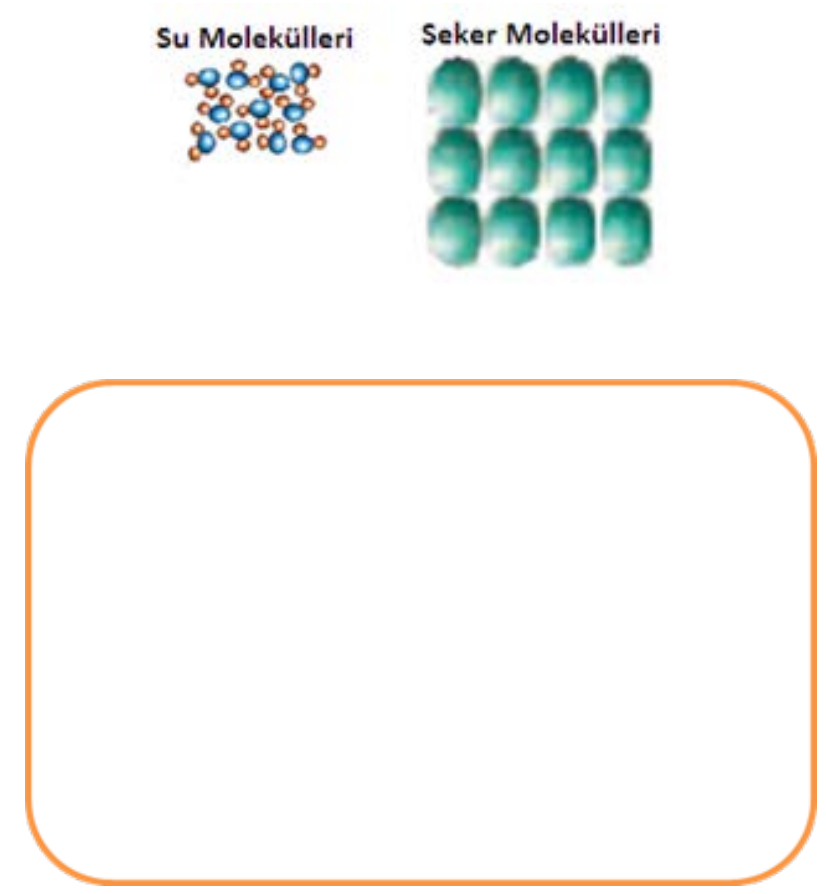

3. Aşağıdaki dereceli silindirlerde $50 \mathrm{~mL}$ hacminde su ve $50 \mathrm{~mL}$ hacminde etil alkol vardır. Bu su ve etil alkol altta bulunan 100 ml lik dereceli silindire dökülüp karıştırılıyor. Etil alkolün su içerisinde çözünebildiği 
düşünüldüğünde elde edilen çözeltinin tanecik modelini toplam hacmi düşünerek $100 \mathbf{~ m L}$ lik dereceli silindirin içine çiziniz (Aşağıda su ve etil alkolün tanecik modelleri verilmiş̧tir, renkli kalemleri gerekli gördüğünüz şekilde kullanabilirsiniz).

Su Molekülleri

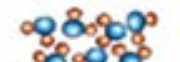

808080

Etil Alkol Molekülleri
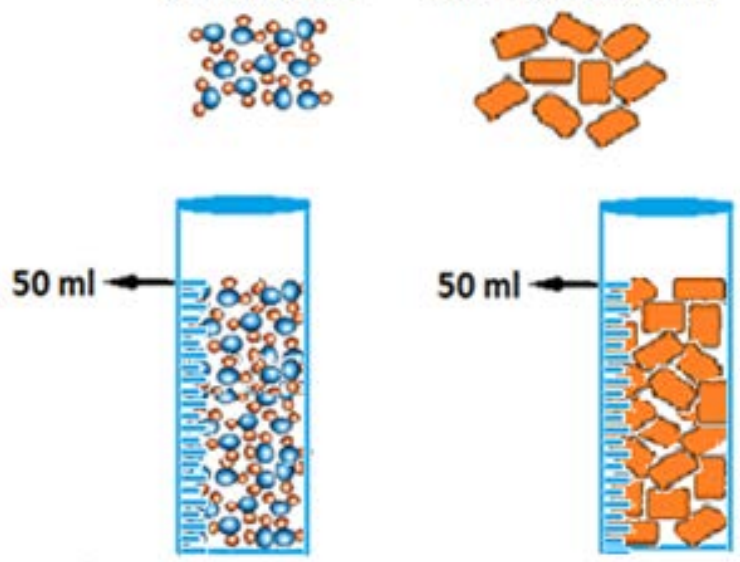

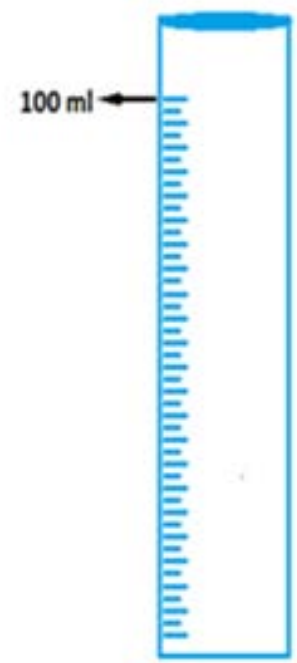

